\title{
Inactivation of pollen and other effects of genome-plastome incompatibility in Oenothera
}

\author{
W. Stubbe ${ }^{1}$ and E. Steiner ${ }^{2,3}$ \\ ${ }^{1}$ Botanical Institute and Botanical Garden, Heinrich-Heine-University, Düsseldorf, Germany \\ ${ }^{2}$ Department of Biology and Matthaei Botanical Gardens, University of Michigan, Ann Arbor, Michigan, USA
}

Received December 22, 1997

Accepted May 13, 1998

\begin{abstract}
A series of strains of the homozygous species Oenothera grandiflora (characterized by the genome BB and plastome III) were combined with plastome IV from O. parviflora (BC-IV) by means of appropriate crosses. An incompatibility between genome $\mathrm{B}$ and plastome IV is expressed in the haplo- and diplophase: (1) B-IV pollen, though normally developed, is largely inactive. The extent of the inactivation varies between different strains and shows a seasonal fluctuation as determined by seed set in outcrossing and selfing experiments. (2) In most of the strains lethality of BB-IV embryos is the rule, leading to empty seeds. This can be ameliorated by including another plastome in the zygotes and developing embryos on account of the biparental plastid transmission in Oenothera. It can best be demonstrated in crosses with a seed parent having normal green plastids of plastome IV and mutated chlorophyll deficient plastids from a different plastome in the pollen parent, leading to variegated progeny as well as a remainder of empty seeds. (3) In about one-half of the strains the BB-IV plants exhibit a temporary bleaching of the virescens type. The incompatibily between genome B and plastome IV does not support the earlier assumption that plastome IV is the ancestor of plastomes II, III, and V. Instead, a precursor plastome is postulated from which plastomes II, III, and IV are descended. While plastome I can be derived from II, only plastome V can be descended from plastome IV.
\end{abstract}

Key words: Onagraceae, Oenothera grandiflora. Incompatibility between genome and plastome, pollen inactivation, embryo lethality, chlorophyll deficiency, pedigree of plastome evolution.

\footnotetext{
${ }^{3}$ Deceased August 28, 1998.
}

Investigations of the interaction of genome and plastome (Stubbe 1959) have shown that subsection Oenothera of the section Oenothera comprises three basic genomes (A, B, C) and five plastomes (I-V), the former being arranged in 13 species in either a homozygous or complex-heterozygous state (Raven et al. 1979, Stubbe and Raven 1979a, Dietrich et al. 1997).

In crossing experiments in which the plastomes are combined with genomes with which they do not occur naturally, the progenies frequently show a disturbed development. Such incompatibility between genome and plastome is most noticeably expressed as different types of chlorophyll deficiencies. Due to the biparental transmission of plastids in Oenothera, interspecific hybrids are often variegated when one of the parental plastid types becomes green while the other turns pale. These phenomena are called hybrid paleness and hybrid variegation. Variegated plants may also be obtained by crossing if one of the partners carries mutated chlorophyll deficient plastids.

The number of plastids derived from the female parent is generally greater than that from the male parent, but the proportion of both varies greatly from cross to cross. Schötz (1954) concluded that the degree of variegation (variegation value or "Scheckungswert") is based on differences in the multiplication rate of the five plastid types. As a result, a competition takes place within the zygote and the "mixed" cells derived from it, leading to a deviation from the original proportion of maternal and paternal plastids during the development of the embryo and young plant. In apparently compatible genome- 
plastome combinations the extent of plastid transmission to the progeny led to recognition of the following series: I > III > II > V > IV (Schötz 1954, 1974, 1975). Recently, the influence of the genome and plastome on plastid transmission has been reinvestigated in greater detail by Chiu and Sears (1993).

Another expression of the incompatibility between genome and plastome concerns pollen inactivation. This can be observed when genome B is combined with plastome IV (Stubbe 1959, 1960; Göpel 1967, 1970). (Other combinations showing the same effect will not be considered here.) The B genome is found in the homozygous species $O$. grandiflora (BB) and in the complex-heterozygous $O$. nutans Atkinson $\left(\mathrm{B}_{1} \mathrm{~B}_{2}\right)$ (syn. O. austromontana Munz) studied in detail by Wasmund (1984). In both cases it normally occurs with plastome III. It is also found in the complex-heterozygous species $O$. biennis (AB) (Raven et al. 1979).

Plastome IV occurs in the complex-heterozygous species $O$. parviflora and $O$. oakesiana (AC). These two species represent a refuge for plastome IV; they cannot be invaded by the other plastomes via crosses since the latter are not compatible with the $\mathrm{C}$ genome. Otherwise, because of its low multiplication rate, plastome IV would be displaced by the faster multiplying plastomes. Because of the low multiplication rate and its relatively greater tolerance with respect to the normal functioning of the chloroplasts when associated with the three genomes $\mathrm{A}, \mathrm{B}$, and $\mathrm{C}$, plastome IV is regarded as the most primitive of the five plastomes in subsection Oenothera (e.g. Stubbe 1959).

The inactivation of one of the two complexes in a complex-heterozygous species of Oenothera is a familiar phenomenon. In the heterogamous species $O$. parviflora and $O$. oakesiana only the C complex is transmitted by the pollen; the inactivation of the partner complexes B and A is achieved by pollen lethals. In $O$. biennis subsp. centralis self-incompatibility (Si) genes have been demonstrated in the $\mathrm{B}$ complex which prevent the formation of BB homozygotes in the normally self-pollinating species (Steiner 1956, 1957). [More recently Si genes were also demonstrated in $O$. grandiflora (Stubbe and Raven 1979b).] In strains of $O$. biennis subsp. caeciarum, however, the B complex lacks Si genes and functions as the pollen complex, while the partner complex A carries a pollen lethal. In addition, the B complex frequently carries a sporophytic lethal by which the homozygotes are eliminated as proembryos, leading to empty seeds (Renner 1916).

In the context of the present investigation it should be noted that Renner (1919) first observed that the gaudens (B) complex of $O$. lamarckiana de Vries becomes inactivated in the pollen when it is transferred into the cytoplasm of $O$. muricata (ACIV). The extra-chromosomal component of this incompatibility was later shown to be localized in the plastids (Stubbe 1959, 1960). The phenomenon of plastome-dependent pollen inactivation was studied in detail by Göpel $(1967,1970)$. He utilized different strains of $O$. suaveolens (a species which can be assigned to $O$. biennis subsp. caeciarum) in which the $\mathrm{B}$ complex flavens is free of pollen lethals and $\mathrm{Si}$ genes. It was found that the inactivation of the B-IV pollen was not always absolute. Thus, after selfing of the AB-IV combination $(O$. suaveolens with plastome IV) occasional fruits with a few seeds occur which give rise to progeny of the parental phenotype. That these rare active pollen grains were genetically altered by mutation or crossing-over could be excluded. Through breeding experiments it could be demonstrated that the genetic constitution of the sporophyte also influences the pollen activity. This was further confirmed by physiological investigations (Göpel 1976). However, O. suaveolens presented two disadvantages in these investigations: First, the pollen is not homogenous, since the albicans complex forms $50 \%$ empty grains due to its pollen lethals; further, an additional percentage of empty grains results from meiotic failures. Second, even if by crossing different strains of $O$. suaveolens, flavensflavens homozygotes (BB) were obtained free of sporophytic lethals (cf. Stubbe 1953), these were weak because of their limited compatibility with plastome II which had to be replaced by plastome III. At that time plastome III was only available from $O$. lamarckiana and the crosses led to the falcifolia syndrome (Stubbe $1970,1989 a, b)$.

With the more recent availability of a number of strains of $O$. grandiflora which possess a homozygous B genotype combined with plastome III, it became feasible to reinvestigate plastome-dependent pollen inactivation utilizing these vigorous homozygous forms. More than 20 strains of these large flowered forms in our collection were outfitted with plastome IV through appropriate crossings. The expectation was that among these phenotypically diverse BB-IV combinations, we would find some with inactive as well as active pollen. The phenomenon of plastomedependent pollen inactivation could then be studied in depth with physiological and molecular biological techniques. Moreover, the results should shed light on the evolution of the five plastomes in the subsection Oenothera and may provide a test of the hypothesis that plastome IV is primitive and the one from which the others evolved. 


\section{Materials and methods}

The strains of Oenothera grandiflora L.'Her. here investigated are listed in Table 1. A description of their characteristics is given in the publications of Steiner and Stubbe (1984, 1986), Schumacher et al. (1992), and Schumacher and Steiner (1993).

Most of the strains when grown in the experimental garden at the University of Düsseldorf, flower late in the season and therefore need short-day treatment in a special greenhouse. Such treatment may be necessary in order to make crosses with those plants flowering under long-day conditions.

The compatibility relations between different genomes and plastomes with regard to plastid development are described by Stubbe (most recently in Stubbe 1989c, also reproduced in Schumacher et al. 1992 and Harte 1994).

Plastome III of $O$. grandiflora can be exchanged with plastome IV of a strain of $O$. parviflora without difficulty, provided certain complex-heterozygous hybrids with suitable chromosome arrangements which have already been combined with plastome IV and mutated chlorophylldeficient plastids from the other plastomes, are utilized. In the present investigation the complex combinations of albicans Grado-undans (AA) or albicans Grado-percurvans (AC) were used as seed parents. The albicans complex is transmitted exclusively by the egg cell; (undans and percurvans are pollen complexes). The exchange of plastomes is accomplished by a crossing scheme, an example of which is described in Stubbe (1989c):
First, a complex-heterozygous variegated hybrid with the genetic constitution of albicans- ${ }^{\mathrm{h}}$ grandiflora $(\mathrm{AB})$ is produced. It bears mutated plastids (II $\gamma$ ) from the seed parent and plastid type III from the pollen parent. (The diakinesis configuration is generally a circle of 14; in some cases a circle of 8 and a circle of 6 is observed, but due to the lethals in albicans the only segregants are the parental complexes $\mathrm{A}$ and $\mathrm{B}$ ). White tissues of this variegated hybrid AB-II $\gamma /$ III, supply pollen which transmits mutated plastids with the ${ }^{\mathrm{h}}$ grandiflora complex (B-II $\gamma$ ). If a complexheterozygous hybrid which previously was combined with plastome IV (e.g. AC-IV), is pollinated with B-II $\gamma$, variegated progeny of idiotype $\mathrm{AB}-\mathrm{IV} / \mathrm{II} \gamma$ is obtained. This hybrid produces two types of egg cells in its green parts, namely albicans (A-IV) and ${ }^{\mathrm{h}}$ grandiflora (B-IV), but only $\mathrm{B}-\mathrm{IV}$ pollen. Its white parts give rise to corresponding gametes but with mutated plastids. To obtain a grandiflora with plastome IV (BB-IV), the hybrid is self-pollinated. As will be explained later, it may be necessary to pollinate flowers of green sectors with pollen from white tissues. Using this procedure all the strains listed in Table 1 were combined with plastome IV. (One cannot always rely on the green color of the tissue. In some cases plastome III was obtained instead of plastome IV. The tissues which should have possessed mutated plastids exclusively may have also carried some proplastids of type III which could not be detected macroscopically. There is at present no indication of gene exchange by recombination between different plastomes in Oenothera, although theoretically possible (Medgyesy et al.1985). In any case, a test for the presence of

Table 1. Oenothera grandiflora strains used in the present investigation (for details see Steiner and Stubbe 1984 and 1986)

\begin{tabular}{|c|c|c|c|}
\hline Collection & Collector & Date & Remarks \\
\hline Avalon, FL & R. K. Godfrey & Oct. 1975 & several lines \\
\hline Bay Minette, AL & E. Steiner & Oct. 1983 & two lines \\
\hline Bellamy, AL & $\begin{array}{l}\text { Sam B. Jones \& Jud } \\
\text { K. Arrington }\end{array}$ & Aug. 1974 & several lines \\
\hline Bigbee, AL & E. Steiner & Oct. 1983 & \\
\hline Bolinger, AL & E. Steiner & Oct. 1983 & \\
\hline Brewton, AL & E. Steiner & Sept. 1981 & several lines \\
\hline Cantonment, FL & E. Steiner & Oct. 1983 & \\
\hline Castleberry, AL & E. Steiner & Oct. 1983 & two lines \\
\hline Chastang, AL & E. Steiner & Oct. 1983 & three lines \\
\hline County Road 6, AL & E. Steiner & Oct. 1983 & \\
\hline Flomaton, AL & E. Steiner & Oct. 1983 & \\
\hline Frankville, AL & E. Steiner & Oct. 1983 & \\
\hline Monteagle, TN & R. Kral & Sept. 1979 & \\
\hline Seaburry Creek, AL & P. Biebel & Oct. 1962 & two lines \\
\hline Sims Chapel, AL & E. Steiner & Oct. 1983 & \\
\hline Stockton, AL & P. Biebel & Oct. 1962 & two lines \\
\hline \multicolumn{4}{|l|}{ Stockton derived $^{1}$} \\
\hline Tuscaloosa, AL & J. S. Lloyd & Aug. 1944 & \\
\hline York, AL & Sam B. Jones & unknown & several lines \\
\hline
\end{tabular}

"The strain "Stockton derived" is probably a hybrid between strains from Seabury Creek and Stockton, used in experiments by H. Kutzelnigg (1968). 
plastome IV among the plastids should be carried out. This is easily done by determining the shape of the starch grains in the pollen, see below.)

After having replaced plastome III with plastome IV the effects of the exchange can be investigated. Both the diploand haplophases are affected:

1. For determination of the vitality and activity of the B-IV pollen either the hybrid albicans ${ }^{\mathrm{h}}{ }^{\mathrm{grandiflora}}$ (AB-IV) or BB-IV homozygotes can serve as pollen sources. Microscopic examination of a pollen sample is critical in order to estimate the proportion of empty pollen grains and to determine the shape of the starch grains (stained with IKI). In contrast to B-II or B-III pollen which contain pointed angular starch grains, the grains of B-TV pollen are round. In this way the presence of plastome IV can be established.

For the present it was not possible to test germination of pollen on the stigma or on stigma-secreted slime, nor were physiological measurements (e.g. Göpel 1976) carried out. The activity of the B-IV pollen was assessed exclusively by means of seed formation following surplus pollination. On the one hand, this was achieved through self-pollination of the AB-IV hybrids and the BB-IV homozygotes, and, on the other, by pollinating a large-flowered AA-I species, for example $O$. elata, with B-IV pollen. In the latter case the hybrids produced should be of the idiotype AB-I which is phenotypically a lutescens pale, expressed particularly in the cotyledons.

The activity or inactivity of the B-IV pollen is indicated by the fruit development. Within certain limits the size of the capsule depends upon the number of seeds produced (Göpel 1967: 29; Chiu and Sears 1993: Fig. 3). It is worth pointing out that fruits of pollinated flowers which do not produce seeds do not fall off in contrast to those which have not been pollinated. This has also been observed after self pollination of self-incompatible plants.

2. If the B-IV pollen is inactive, BB-IV homozygotes can only be obtained by using pollen carrying a different plastid type, e.g. B-II $\gamma$ pollen. This implies that a variegated progeny (BB-IV/II $\gamma$ ) must be taken into consideration. For entirely different reasons such a procedure proved necessary, as will be reported under "Results".

3. Although this investigation began with examination of plastome-dependent pollen inactivation, it seemed pertinent to also compare the BB-IV plants with the BB-III plants of the original strains.

\section{Results}

As previously pointed out by Steiner and Stubbe (1984, 1986), the various strains of $O$. grandiflora collected in Alabama, Florida and Tennessee show a considerable morphological diversity when grown in the experimental field. The differences relate to the contour of the leaves, the leaf colour, the branching of the stem, the size of flowers and fruits, the distribution and intensity of anthocyanin pigmentation as well as the pubescence of different parts of the plant body. Important differences also exist with regard to the initiation of flower formation in response to the day length. Late blooming can be overcome by short-day treatment after the plants have broken the rosette stage in long-day conditions. In spite of the wide variation of strains selected from natural populations (and now maintained as pure lines), their phenotypes still conform to the basic genotype B which is most compatible with plastome III.

It seems appropriate in this context to recapitulate the general appearance of the grandiflora phenotype: When sown in the greenhouse during winter, the normally biennial plants complete their life cycle in the current growing season. They are transferred to the experimental field in April or May. After having broken the rosette stage under long-day conditions the plants develop an erect main stem with side branches arising from its base. The broad rosette leaves may have a deeply scalloped contour. Leaf pigmentation is generally a light yellowish green which is characteristic for most BB-III genotypes, whereas the combination of a $\mathrm{B}$ genome with an $\mathrm{A}$ or $\mathrm{C}$ complex shows a deeper green. Usually the leaves are spotted with red flecks (resulting from the presence of the dominant Maculans gene, Renner 1942). The anthocyanin pigmentation of stems and leaves varies widely. The large flowers appear on numerous small branches near the tip of the stem. While in Düsseldorf most species of Oenothera start flowering under long-day conditions in June/July, the strains of $O$. grandiflora usually come into bloom in the short days between September and November. However, earlier flowering was observed in July and August with lines selected from the strains Bellamy, Bigbee, Brewton, County Road 6, Flomaton, Frankville, Monteagle, Tuscaloosa and York.

It may be mentioned that as far as possible selfcompatible lines were used, though $\mathrm{Si}$ genes are present in many strains. In the strain from Monteagle, however, a self-compatible line is not available, thus, selfing of BB-IV must be replaced by crossing of lines with different $\mathrm{Si}$ genes. Furthermore, we do not consider the limited chromosomal variability between pure lines as significant, since it is without influence on the phenotype.

When plastome III was replaced by plastome IV, we found that the different strains did not react alike. Differences occurred not only with regard to pollen activity (which was the initial thrust of this investigation), but also with regard to the viability of embryos, 
the greening of the leaves and the vigour, growth and branching of the plants.

The phenomenon of pollen inactivation when a B complex is combined with plastome IV, was studied in detail by Göpel (1967) using the flavens complex of $O$. suaveolens. The present investigation of more than 20 grandiflora complexes largely confirms Göpel's observations: B-IV pollen grains generally contain a healthy protoplast which is plasmolysable. B-I, B-II, and B-III pollen contain pointed angular or spindle shaped starch grains; in contrast, B-IV pollen has round or nearly round starch grains (Fig. 1). Pollen tube formation is usually inhibited, but the inactivation of B-IV pollen is not always absolute; on occasion several grains function normally and fertilize egg cells, leading to seed development. In so far our results are in good agreement with the rigorous investigations of Göpel (1967). Beyond that employing different homozygous strains of $O$. grandiflora led to new findings.

Our experiments were mainly extended after the acquisition of additional strains in 1984. Initially the method of choice to determine pollen activity was selfing. The majority of AB-IV and BB-IV failed to set seed (records not shown), but could be maintained by means of variegated progeny when B-IV pollen was replaced by pollen with mutated plastids of plastome II or III. A further test of pollen activity was carried out by pollinating AA-I plants with B-IV pollen from $\mathrm{AB}-\mathrm{IV}$ and $\mathrm{BB}-\mathrm{IV}$ plants (Table 2). These experiments generally showed that some seeds were produced, the size of the fruit corresponding to the amount of seeds in it, but a not predictable fluctuation of B-IV pollen efficiency persisted. However, in 1992 the fluctuation in most of the strains showed a remarkable pattern, namely, when AA-I species were pollinated between July 16 and 22, seed production was scarce or lacking, but when the experiments were repeated with the same plants a month later, seed set was normal or nearly so (Table 2A). A partial repetition of the test in 1993 gave, with only a few exceptions, similar results. These experiments were taken up again in 1996 to determine if the result of 1992 could be reproduced. For practical reasons the experiments were carried out a week later between July 22 and 31 and some of the tests were done with plants in the greenhouse. The results, shown in Table 2B, do not confirm those of 1992 in which a better seed set was obtained in August than in July; rather the trend was the reverse. Nevertheless, completely inactive B-IV pollen due to incompatibility between genome and plastome is no longer to be expected in either of the different strains. Whether external conditions directly or the developmental stage of the plants in relation to their age is responsible for this previously unobserved seasonal fluctuation is not known. Further, in some races the B-IV pollen is active enough to yield normal seed production at all times. This applies mainly to the strains Bellamy, Cantonment, Flomaton, Sims Chapel, Tuscaloosa and York. We assume that in these cases the B-IV pollen contains a relatively high percentage of active grains, but is not as vigorous as the B-III Pollen.

The results of the selfings of $\mathrm{AB}-\mathrm{IV}$ and $\mathrm{BB}-\mathrm{IV}$ plants (Tables 3 and 5) demonstrate by the frequently imperfect fruit development and reduced seed set also the unsatisfactory function of B-IV pollen. In addition to that, imperfect seed development points to a diminished vitality and vigour of the containing embryos.

If seeds from selfed complex-heterozygous $\mathrm{AB}$ IV plants are grown (Table 4), two types of offspring are expected $(\mathrm{AB}$ and $\mathrm{BB})$, but in the majority of the strains only AB-IV plants appear. A great part of the normally developed seeds is empty. Obviously, embryo development ceased early on; together with the imperfectly developed seeds the empty are regarded as mainly representing BB-IV homozygotes. (The proportion may deviate widely from a $1: 1$ ratio, presumably due to embryo-sac competition.) In other words, the BB-IV embryos are lethal.

In some strains BB-IV embroys from selfed ABIV plants developed normally yielding a certain portion of seeds capable of germination. If such BBIV plants are selfed, a great deal of the seeds is empty (Table 6). Viable BB-IV embryos have been observed with strains Avalon, Bay Minette, Bellamy, Cantonment, Castleberry B, Chastang 2, Flomaton, Frankville, Seabury Creek 2, Sims Chapel, Stockton 2, Stockton derived, Tuscaloosa and York.

Of particular interest is the fact that the failure of embryo development can be overcome, if a second plastid type is contributed to the zygote by the pollen. Usually a chlorophyll-deficient mutant of plastome II or III suceeds well in combination with plastome IV in the resulting variegated progeny. Since some empty seeds are still obtained, a sufficient number of plastids does not always seem to be distributed to the part of the zygote which gives rise to the embryo proper, and which is necessary to overcome the lethal effect of plastome IV. The only case in which the lethality of BB-IV embryos could not yet be overcome by using pollen with plastome II or III, was with $A B-I V$ of County Road 6 as seed parent. Generally, using this procedure the BB-IV homozygotes can be brought to full development. Actually the mutated plastome II or III is no longer necessary for further development of BB-IV tissue immediately after germination. Thus, it 

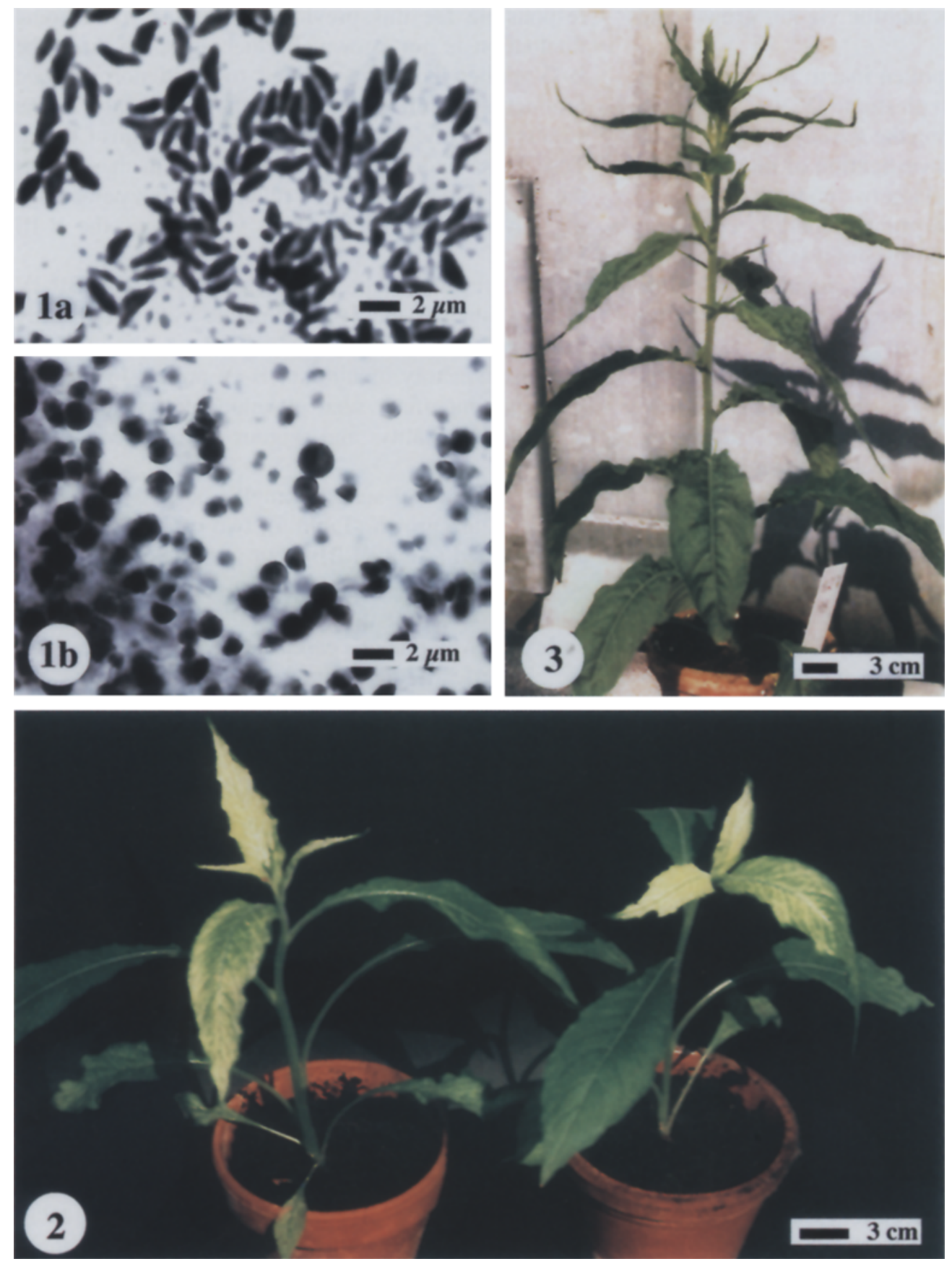

Fig. 1. Oenothera starch grains. $a$ B-III pollen, $b$ B-IV pollen. - Fig. 2. Oenothera BB-IV plants showing the virescens type of chloroplast deficiency. - Fig. 3. Oenothera BB-IV plant of strain Stockton 1 with an irregular contour of the upper leaves

becomes possible to compare the BB-IV plants with the original $O$. grandiflora strain with regard to phenotypic differences. This proved worthwhile especially for chloroplast development. Namely, in several of the strains a bleaching called virescens (Fig. 2) occurs similar to that known in the combination AA-III
(Stubbe 1995, 1959). The expression of this character is not always strong. We observed the virescens phenotype in the following strains: Avalon, Bigbee, Cantonment (only slightly), Frankville (young plants), Monteagle, Stockton 2, Stockton derived, Tuscaloosa and York. In addition to this, the virescens character 
appeared in special lines which were obtained by crossing a self-compatible with a self-incompatible complex of the strains Bellamy, Castleberry B and Seabury Creek 2.

As already observed in the case of AA-III, the virescens character of the BB-IV tissue can be influenced by tissues with mutated plastids (e.g. II $\gamma$ ) in such a way that the bleaching is suppressed. Thus, a plant may contain three types of colored tissues, virescent BB-IV, green BB-IV and mutated BB-II $\gamma$. This phenomenon was described earlier with the idiotype albicans-velans (AA) with plastome III and II $\beta$ (Stubbe 1958; see also Harte 1994: plate 2e).

Another phenotypic expression of incompatibility between the B genome and plastome IV appeared only in the strain Stockton 1 as an irregular contour of the upper cauline leaves (Fig. 3).

The incompatibility reactions described above serve to supplement the earlier versions of Stubbe's scheme (Stubbe 1959) by adding to the BB-IV square the symbols for virescens and lethality (Stubbe 1989c).

\section{Discussion}

As known from earlier experiments (Renner 1919; Stubbe 1959; Göpel 1967, 1970) genomes of the B type derived from complex-heterozygous species are incompatible with plastome $\mathrm{IV}$ of $O$. parviflora because of the inactivation of the B-IV pollen. In order to determine if this behavior is also true of different strains of $O$. grandiflora (BB-III), the ancestors of which must have been ancestors of all B genomes, more than 20 strains of $O$. grandiflora were combined with plastome IV (Table 1). At least some of these new combinations were expected to show a complete inactivation of the B-IV pollen.

As indicated by seed set (Tables 2, 3 and 5), no strain shows an absolute inactivation of B-IV pollen, although distinct differences occur among the strains of various geographic origin. This is not too surprising, since the strains also differ greatly in phenotype. Further, the 1992 tests show differences between most strains in the seed set obtained in July and that obtained in August. These may be the result of developmental or environmental influences on the pollen parent, the sporophyte, during pollen grain development, or on the male gametophyte itself when it germinates and forms the pollen tube. At the present it has not been possible to establish a causal connection with climatic conditions. Sometimes a difference exists between plants of the same origin, when grown in the field and in the greenhouse, which suggests environmental influence (e.g. Table 2, Castleberry B 93-396).
The fluctuating nature of the inactivation of B-IV pollen is an incompatibility between genome and plastome that can be compared to disturbances of chloroplast development which lead to an incomplete bleaching of the leaves and the occasional recovery of their normal green colour. One can assume that differences in the activity of B-IV pollen occur in different parts of the anther.

The above results confirm those of Göpel (1967, 1970, 1976) who used mainly the flavens complex of different strains of $O$. suaveolens. His genetic and physiological findings are presented in great detail and his approach could well be profitably applied to further investigations on the phenomenon of pollen inactivation of $O$. grandiflora.

Beyond that, several hitherto unknown aspects of the vitality of BB-IV sporophytes were observed: The vitality and vigour of BB-IV homozygotes of the different strains varies. Two developmental stages are critical in this respect. The first is early embryogenesis and formation of viable seeds. The second concerns the plastid development in the cotyledons and the leaves of the rosette and shoot.

That the BB-IV homozygotes are lethal in most of the strains during the early development of the embryo was an unexpected finding. In some strains in which selfing of BB-IV plants give viable progeny (Table 6), a portion of seeds is empty, pointing to a diminished vigor of the embryos in an early stage of development.

Fortunately the lethality of BB-IV embryos can be overcome by introducing a different plastid type into the zygote from the pollen parent. Since the partner plastome is only necessary to overcome the critical embryonic stage, mutated chlorophyll-deficient plastids can be used. This neutralization of the incompatibility during the embryonic stage by a second plastid type allows us to grow all of the strains with plastome IV to maturity. Thus it is possible not only to test the pollen quality but also to compare the BB-IV phenotype with that of the original BB-III plants.

In about half of the strains a virescens paleness of the BB-IV is observed. This is new, since BB-IV combinations from complex-heterozygous species always showed normal greening. Virescens paleness was known earlier in the combination AA-III and occasionally in AB-III.

In general, the virescens character reduces the vigor of the shoot system, but this effect may be neutralized in variegated plants by the influence of the mutated plastids. Frequently, the virescens bleaching is overridden when tissues with mutated plastids are superimposed on those with plastome IV. Thus, tissues with green plastids occur along with those with 
Table 2. A, B. Determination of the activity of Oenothera B-IV pollen from AB-IV and BB-IV plants by pollinating AA-I plants and counting the seeds produced, carried out with plants grown in the field $(F)$ or in the greenhouse $(G)$. Part $A$ refers to 1992 and 1993 , part $B$ to 1996 . Optimum seed production of the chiefly used seed parent $O$. elata strain Chapultepec is 550-600 seeds per capsule

A

\begin{tabular}{|c|c|c|c|c|c|c|c|}
\hline Strain & $\begin{array}{l}\text { Culture } \\
\text { number }\end{array}$ & Genotype & $\mathrm{F}$ or $\mathrm{G}$ & $\begin{array}{l}\text { Date of } \\
\text { pollination }\end{array}$ & $\begin{array}{l}\text { Seeds } \\
\text { obtained }\end{array}$ & $\begin{array}{l}\text { Date of } \\
\text { pollination }\end{array}$ & $\begin{array}{l}\text { Seeds } \\
\text { obtained }\end{array}$ \\
\hline \multirow[t]{3}{*}{ Avalon } & $92-109$ & $\mathrm{AB}$ & $\mathrm{G}$ & 16.7 .92 & 65 & 14.8 .92 & 280 \\
\hline & $92-116$ & $\mathrm{AB}$ & $\mathrm{F}$ & 14.7 .92 & 57 & 14.8 .92 & 121 \\
\hline & $92-124$ & $A B$ & $\mathrm{~F}$ & 20.7 .92 & 195 & 14.8 .92 & 215 \\
\hline \multirow[t]{2}{*}{ Bay Minette A } & $92-127$ & $\mathrm{AB}$ & $F$ & 20.7 .92 & 80 & & \\
\hline & $92-128$ & $\mathrm{AB}$ & $\mathrm{F}$ & 16.7 .92 & 26 & 14.8 .92 & 115 \\
\hline \multirow[t]{11}{*}{ Bellamy } & $92-131$ & BB & G & 22.7 .92 & 430 & & \\
\hline & $92-133$ & $\mathrm{AB}$ & $\mathrm{F}$ & 20.7 .92 & 472 & & \\
\hline & $92-135$ & $\mathrm{AB}$ & $\mathrm{G}$ & 22.7 .92 & 200 & & \\
\hline & $92-137$ & $\mathrm{AB}$ & $\mathrm{F}$ & 20.7 .92 & 444 & & \\
\hline & $92-139$ & $\mathrm{AB}$ & $\mathrm{F}$ & 21.7 .92 & 442 & & \\
\hline & $92-139$ & $\mathrm{BB}$ & G & 22.7 .92 & 324 & & \\
\hline & $92-140$ & BB & G & 22.7 .92 & 260 & & \\
\hline & $93-336$ & BB & $\mathrm{G}$ & & & 21.8 .93 & 505 \\
\hline & $93-337$ & $\mathrm{BB}$ & $\mathrm{F}$ & & & 21.8 .93 & 551 \\
\hline & $93-340$ & $\mathrm{BB}$ & $\mathrm{G}$ & & & 21.8 .93 & 517 \\
\hline & $93-242$ & $\mathrm{BB}$ & $\mathrm{F}$ & & & 21.8 .93 & $>500$ \\
\hline \multirow[t]{5}{*}{ Bolinger } & $92-145$ & $\mathrm{AB}$ & $\mathrm{F}$ & 21.7 .92 & 164 & & \\
\hline & $92-146$ & $\mathrm{AB}$ & $\mathrm{F}$ & 21.7 .92 & 202 & & \\
\hline & $91-306 a$ & $\mathrm{AB}$ & $\mathrm{F}$ & 21.7 .92 & 86 & & \\
\hline & $93-353$ & $\mathrm{AB}$ & F & & & 21.8 .93 & 220 \\
\hline & $93-353$ & BB & $F$ & & & 6.10 .93 & 270 \\
\hline \multirow[t]{4}{*}{ Brewton } & $92-150$ & $\mathrm{AB}$ & $F$ & 22.7 .92 & 138 & & \\
\hline & $92-150$ & BB & $F$ & 22.7 .92 & 130 & 14.8 .93 & 342 \\
\hline & $93-368-1$ & BB & $F$ & & & 21.8 .93 & 233 \\
\hline & $93-368-2$ & $\mathrm{BB}$ & $\mathrm{F}$ & & & 21.8 .93 & 147 \\
\hline \multirow[t]{3}{*}{ Cantonment } & $92-158$ & $\mathrm{AB}$ & $\mathrm{F}$ & 21.7 .92 & 45 & 14.8 .92 & 359 \\
\hline & & & & & & 18.8 .92 & 448 \\
\hline & $92-160$ & $\mathrm{AB}$ & $\mathrm{F}$ & 21.7 .92 & 150 & & \\
\hline \multirow[t]{3}{*}{ Castleberry B } & $92-170$ & $A B$ & $\mathrm{~F}$ & 21.7 .92 & 98 & 14.8 .92 & 187 \\
\hline & $93-396-1$ & BB & G & & & 21.8 .93 & 374 \\
\hline & $93-396-2$ & $\mathrm{BB}$ & $\mathrm{F}$ & & & 20.8 .93 & 40 \\
\hline County Road 6 & $91-350$ & $\mathrm{AB}$ & $\mathrm{F}$ & 22.7 .92 & 0 & 22.8 .92 & 256 \\
\hline \multirow[t]{4}{*}{ Flomaton } & $92-192$ & $\mathrm{BB}$ & $\mathrm{G}$ & 22.7 .92 & 22 & 14.8 .92 & 190 \\
\hline & $93-427$ & $\mathrm{BB}$ & $\mathrm{G}$ & & & 21.8 .93 & 306 \\
\hline & $93-428$ & BB & $\mathrm{G}$ & & & 21.8 .93 & 448 \\
\hline & $93-430$ & BB & $\mathrm{G}$ & & & 21.8 .93 & 236 \\
\hline \multirow[t]{2}{*}{ Frankville } & $92-206$ & $\mathrm{AB}$ & $\mathrm{F}$ & & & 19.8 .92 & 66 \\
\hline & $92-209 b$ & BB & $\mathrm{G}$ & 22.7 .92 & 90 & 14.8 .92 & 280 \\
\hline \multirow[t]{2}{*}{ Seaburry Creek 1} & $92-239$ & $\mathrm{AB}$ & $\mathrm{F}$ & & & 17.8 .92 & 450 \\
\hline & $92-240$ & $\mathrm{AB}$ & $\mathrm{G}$ & 22.7 .92 & 26 & 14.8 .92 & 207 \\
\hline Seaburry Creek 2 & $92-260-1$ & $\mathrm{BB}$ & $\mathrm{G}$ & 22.7 .92 & 22 & 14.8 .92 & 244 \\
\hline \multirow[t]{3}{*}{ Sims Chapel } & $92-272$ & $\mathrm{AB}$ & $\mathrm{F}$ & 22.7 .92 & 137 & & \\
\hline & $92-273 a$ & $\mathrm{AB}$ & $\mathrm{F}$ & & & 14.8 .92 & 674 \\
\hline & $93-479$ & BB & $\mathrm{F}$ & & & 21.8 .93 & 577 \\
\hline Stockton 1 & $92-274$ & BB & $\mathrm{G}$ & 22.7 .92 & 0 & 14.8 .92 & 204 \\
\hline Stockton 2 & $92-284$ & BB & $\mathrm{G}$ & 22.7 .92 & 0 & 14.8 .92 & 288 \\
\hline Stockton derived & $92-216$ & $\mathrm{BB}$ & $\mathrm{G}$ & 22.7 .92 & 40 & 17.8 .92 & 380 \\
\hline Tuscaloosa & $92-290$ & BB & $G$ & 22.7 .92 & 464 & & \\
\hline York & $92-299$ & $A B$ & $\mathrm{~F}$ & 19.7 .92 & 106 & & \\
\hline
\end{tabular}


$\mathbf{B}$

\begin{tabular}{|c|c|c|c|c|c|c|c|}
\hline Strain & $\begin{array}{l}\text { Culture } \\
\text { number }\end{array}$ & Genotype & $\mathrm{F}$ or $\mathrm{G}$ & $\begin{array}{l}\text { Date of } \\
\text { pollination }\end{array}$ & $\begin{array}{l}\text { Seeds } \\
\text { obtained }\end{array}$ & $\begin{array}{l}\text { Date of } \\
\text { pollination }\end{array}$ & $\begin{array}{l}\text { Seeds } \\
\text { obtained }\end{array}$ \\
\hline \multirow[t]{3}{*}{ Bay Minette A } & $96-325$ & $\mathrm{AB}$ & $\mathrm{F}$ & 26.7 .96 & 148 & 2.9 .96 & 48 \\
\hline & $96-328$ & BB & $\mathrm{G}$ & 29.7 .96 & 87 & 23.8 .96 & 137 \\
\hline & $96-329 a$ & $\mathrm{AB}$ & $F$ & 26.7 .96 & 75 & 2.9 .96 & 0 \\
\hline \multirow[t]{5}{*}{ Bellamy } & $96-335-1$ & $\mathrm{BB}$ & $\mathrm{G}$ & & & 1.9 .96 & 185 \\
\hline & $96-335-2$ & $\mathrm{BB}$ & $\mathrm{G}$ & & & 2.9 .96 & 156 \\
\hline & $96-343 a$ & $\mathrm{BB}$ & G & 31.7 .96 & 271 & 24.9 .96 & 38 \\
\hline & $96-346-1$ & $\mathrm{BB}$ & G & 31.7 .96 & 320 & 23.8 .96 & 304 \\
\hline & $96-346-2$ & $\mathrm{BB}$ & G & 22.7 .96 & 434 & & \\
\hline \multirow[t]{8}{*}{ Bigbee } & $96-349 b$ & $\mathrm{BB}$ & G & 22.7 .96 & 27 & 22.8 .96 & 122 \\
\hline & $96-351$ & $\mathrm{AB}$ & $\mathrm{F}$ & 26.7 .96 & 54 & 2.9 .96 & 0 \\
\hline & $96-353 a$ & $\mathrm{AB}$ & $\mathrm{F}$ & 26.7 .96 & 71 & 2.9 .96 & 0 \\
\hline & $96-353 a$ & BB & $\mathrm{G}$ & 25.7 .96 & 67 & 23.8 .96 & 214 \\
\hline & $96-353 b$ & $\mathrm{BB}$ & $\mathrm{G}$ & 22.7 .96 & 100 & & \\
\hline & $96-354-1$ & $\mathrm{BB}$ & $\mathrm{G}$ & & & 23.8 .96 & 274 \\
\hline & $96-354-2$ & BB & $\mathrm{G}$ & & & 28.8 .96 & 275 \\
\hline & $96-355 a$ & BB & $\mathrm{G}$ & 25.7 .96 & 130 & 23.8 .96 & 210 \\
\hline \multirow[t]{2}{*}{ Bolinger } & $96-357 \mathrm{a}$ & $\mathrm{AB}$ & $\mathrm{F}$ & 26.7 .96 & 320 & 2.9 .96 & 328 \\
\hline & $96-357 b$ & BB & $\mathrm{G}$ & 25.7 .96 & 287 & 23.8 .96 & 169 \\
\hline \multirow[t]{4}{*}{ Brewton } & $96-361 b$ & $\mathrm{BB}$ & $\mathrm{G}$ & & & 23.8 .96 & 84 \\
\hline & $96-362$ & $\mathrm{AB}^{\mathrm{A}}$ & $\mathrm{F}$ & 26.7 .96 & 348 & 2.9 .96 & 128 \\
\hline & $96-364$ & BB & $\mathrm{G}$ & 31.7 .96 & 370 & 23.8 .96 & 228 \\
\hline & & & & & & 28.8 .96 & 288 \\
\hline \multirow[t]{5}{*}{ Cantonment } & $96-366 a$ & BB & $\mathrm{G}$ & & & 23.8 .96 & 163 \\
\hline & $96-366 b$ & $\mathrm{AB}$ & $\mathrm{F}$ & 26.7 .96 & 228 & 2.9 .96 & 263 \\
\hline & $96-368 a$ & $\mathrm{BB}$ & $\mathrm{G}$ & 25.7 .96 & 176 & 23.8 .96 & 178 \\
\hline & $96-368 b$ & $\mathrm{BB}$ & $\mathrm{G}$ & 31.7 .96 & 252 & 22.8 .96 & 431 \\
\hline & $96-369$ & $\mathrm{BB}$ & $\mathrm{G}$ & & & 1.9 .96 & 484 \\
\hline \multirow[t]{3}{*}{ Castleberry B } & $96-371$ & $\mathrm{AB}$ & $\mathrm{F}$ & 26.7 .96 & 371 & 2.9 .96 & 227 \\
\hline & $96-372$ & $\mathrm{BB}$ & $\mathrm{G}$ & 30.7 .96 & 41 & 23.8 .96 & 0 \\
\hline & $96-372$ & $\mathrm{BB}$ & G & 1.8 .96 & 0 & 4.9 .96 & 5 \\
\hline \multirow[t]{2}{*}{ Chastang 7} & $96-378 \mathrm{a}$ & $\mathrm{AB}^{\mathrm{A}}$ & G & 29.7 .96 & 21 & 1.9 .96 & 17 \\
\hline & $96-378 c$ & $\mathrm{AB}^{\mathrm{A}}$ & $\mathrm{G}$ & 31.7 .96 & 217 & 23.8 .96 & 133 \\
\hline \multirow[t]{2}{*}{ County Road 6} & $96-382$ & $\mathrm{AB}$ & $\mathrm{G}$ & & & 23.8 .96 & 0 \\
\hline & $96-383 a$ & $\mathrm{AB}$ & $\mathrm{F}$ & 26.7 .96 & 350 & 2.9 .96 & 0 \\
\hline \multirow[t]{4}{*}{ Flomaton } & $96-385$ & $\mathrm{BB}$ & $\mathrm{G}$ & & & 1.9 .96 & 49 \\
\hline & $96-386 b$ & $\mathrm{BB}$ & $\mathrm{G}$ & 27.7 .96 & 169 & 23.8 .96 & 161 \\
\hline & $96-389 a$ & $\mathrm{AB}$ & $\mathrm{F}$ & 26.7 .96 & 386 & 2.9 .96 & 466 \\
\hline & $96-389 b$ & $\mathrm{AB}$ & $\mathrm{F}$ & & & 2.9 .96 & 78 \\
\hline Frankville & $96-391 a$ & $\mathrm{AB}$ & $\mathrm{F}$ & 26.7 .96 & 131 & 2.9 .96 & 21 \\
\hline \multirow[t]{3}{*}{ Seabury Creek 1} & $96-409$ & $\mathrm{AB}$ & $\mathrm{G}$ & & & 28.8 .96 & 334 \\
\hline & $96-410 a$ & BB & $\mathrm{G}$ & 31.7 .96 & 182 & 26.8 .96 & 245 \\
\hline & $96-410 a$ & $\mathrm{AB}$ & $\mathrm{F}$ & & & 2.9 .96 & 134 \\
\hline \multirow[t]{3}{*}{ Seabury Creek 2} & $96-413$ & $\mathrm{AB}$ & $\mathrm{F}$ & & & 3.9 .96 & 315 \\
\hline & $96-415 b$ & $\mathrm{AB}$ & $\mathrm{G}$ & & & 26.8 .96 & 540 \\
\hline & $96-417 a$ & BB & $\mathrm{G}$ & & & 26.8 .96 & 155 \\
\hline \multirow[t]{4}{*}{ Sims Chapel } & $96-425$ & $\mathrm{AB}$ & $\mathrm{F}$ & 30.7 .96 & 446 & & \\
\hline & $96-425$ & $\mathrm{BB}$ & G & & & 26.8 .96 & 186 \\
\hline & $96-427$ & $\mathrm{BB}$ & G & & & 26.8 .96 & 331 \\
\hline & $96-429 a$ & $\mathrm{BB}$ & G & & & 5.9 .96 & 249 \\
\hline \multirow[t]{5}{*}{ Stockton 1} & $96-430 \mathrm{a}$ & $\mathrm{BB}$ & $\mathrm{G}$ & 22.7 .96 & 332 & 26.8 .96 & 272 \\
\hline & $96-430 a$ & $\mathrm{AB}$ & $\mathrm{F}$ & & & 3.9 .96 & 320 \\
\hline & $96-432$ & $\mathrm{AB}$ & $\mathrm{F}$ & & & 3.9 .96 & 439 \\
\hline & $96-434$ & BB & $\mathrm{G}$ & 27.7 .96 & 268 & 25.8 .96 & 170 \\
\hline & $96-434$ & $\mathrm{BB}$ & $\mathrm{G}$ & & & 29.8 .96 & 308 \\
\hline
\end{tabular}


Table 2 (continued)

B

\begin{tabular}{|c|c|c|c|c|c|c|c|}
\hline Strain & $\begin{array}{l}\text { Culture } \\
\text { number }\end{array}$ & Genotype & $\mathrm{F}$ or $\mathrm{G}$ & $\begin{array}{l}\text { Date of } \\
\text { pollination }\end{array}$ & $\begin{array}{l}\text { Seeds } \\
\text { obtained }\end{array}$ & $\begin{array}{l}\text { Date of } \\
\text { pollination }\end{array}$ & $\begin{array}{l}\text { Seeds } \\
\text { obtained }\end{array}$ \\
\hline \multirow[t]{2}{*}{ Stockton 2} & $96-436 \mathrm{a}$ & $\mathrm{BB}$ & G & & & 26.8 .96 & 127 \\
\hline & $96-439$ & BB & $\mathrm{G}$ & & & 26.8 .96 & 127 \\
\hline \multirow{4}{*}{ Stockton derived } & 96-395a & BB & $\mathrm{G}$ & & & 1.9 .96 & 334 \\
\hline & $96-399$ & $\mathrm{AB}$ & $\mathrm{F}$ & 26.7 .96 & 0 & 2.9 .96 & 199 \\
\hline & $96-400 \mathrm{a}$ & BB & G & & & 25.8 .96 & 368 \\
\hline & & & & & & 29.8 .96 & 252 \\
\hline \multirow[t]{4}{*}{ Tuscaloosa } & $96-441$ & $\mathrm{AB}$ & $\mathrm{F}$ & 31.7 .96 & 416 & 2.9 .96 & 204 \\
\hline & $96-441$ & $\mathrm{BB}$ & $\mathrm{G}$ & & & 27.8 .96 & 394 \\
\hline & $96-443$ & BB & $\mathrm{G}$ & 27.7 .96 & 386 & & \\
\hline & $96-444 a$ & $\mathrm{BB}$ & G & & & 1.9 .96 & 473 \\
\hline \multirow[t]{3}{*}{ York } & $96-448$ & $\mathrm{BB}$ & $\mathrm{G}$ & 28.7 .96 & 396 & 27.8 .96 & 358 \\
\hline & $96-449$ & $\mathrm{BB}$ & $\mathrm{F}$ & 30.7 .96 & 394 & 2.9 .96 & 523 \\
\hline & $96-451$ & $\mathrm{AB}$ & $\mathrm{F}$ & 30.7 .96 & 358 & & \\
\hline
\end{tabular}

virescens paleness and others with pure chlorophylldeficient mutated plastids. This phenomenon was previously observed in AA-III/II $\beta$ combinations (Stubbe 1958).

Since until now a B genome which is fully compatible with plastome IV has not been observed, the question of the evolutionary significance of these results should be considered in the context of Cleland's hypothesis of the evolution of the subsection Oenothera (Cleland 1972: 225): His view was that the different populations evolved in the center of origin, probably Mexico and Central America, then spread in successive waves across the North American continent. The succession of genotypes is expressed in our terminology (Stubbe 1959) as first CC (O. argillicola), then BB $(O$. grandiflora) and finally AA $(O$. elata). According to Cleland (1972: 299-302), this happened as an adaptation to the changing climatic conditions of the Pleistocene. Cleland's original hypothesis regarding the evolution of the subsection Oenothera did not take into account the plastome. However, with the work of Stubbe $(1959,1964)$ on the compatibility relationships of genome and plastome and that of Schötz $(1954,1958)$ on the relative strength of plastid types in competition experiments, it became clear that the evolution of the plastome had to be considered as a significant element in the evolutionary history of the group. The crucial assumption is that plastome IV is primitive. This is based on the low multiplication rate of plastid type IV and its relatively wide compatibility during development with the diploid genomes as described in the scheme of Stubbe $(1959,1989 \mathrm{c})$.
None of the extant homozygous species, however, carries plastome IV. Nevertheless, one of the parents of the hybrid species $O$. parviflora (BC-IV) and O. oakesiana (AC-IV) must have contributed plastome IV; this was most probably the precursor of $O$. argillicola which later acquired plastome V. Of the three basic genotypes, the argillicola genotype is still the most compatible with plastome IV. In contrast to $\mathrm{AA}$ and $\mathrm{BB}, \mathrm{CC}$ shows no restriction of compatibility with plastome IV. The other parents of the hybrid species had probably already acquired more advanced plastomes at the time crossing occurred. Further, the current concept of the origin of the hybrid species requires that at least one of the parents was already a complex-heterozygote, thus insuring that the hybrid would be a constant complex-heterozygote and probably heterogamous from its inception (Stubbe 1980, Wasmund and Stubbe 1986).

Our concept of the evolution of the hybrid species still presents some unsolved problems. If we consider the basic genotype $B$, which is also present in O. biennis (AB-II, BA-III), one may ask whether the genomic constitution of the extant $O$. grandiflora strains correspond to that of the $\mathrm{B}$ complexes in $O$. parviflora and $O$. biennis or have possibly been conserved to some degree in an earlier state. Further, what plastids did the $\mathrm{A}$ and $\mathrm{B}$ genomes carry at that time? It seems most probable that AA was combined with plastome II and BB with plastome III, since O. biennis subsp. caeciarum contains plastome II and subsp. centralis plastome III at present. In the presence of $\mathrm{BC}$ the plastids of plastome II and III 
Table 3. Examples of seed set obtained by selfing of Oenothera AB-IV plants. The A complex is always albicans Grado, the B complex corresponds to the strain in the first column. Abbreviations: $n$ normal seeds, $i$ imperfectly developed seeds, quota in parenthesis, em empty fruits, $s m$ small fruits, me medium-sized fruits, $n m$ normal fruits

\begin{tabular}{|c|c|c|c|c|c|c|c|c|c|c|c|c|c|}
\hline \multirow[t]{2}{*}{ Strain } & \multirow[t]{2}{*}{$\begin{array}{l}\text { Culture } \\
\text { number }\end{array}$} & \multirow[t]{2}{*}{$\begin{array}{l}\text { Date of } \\
\text { first } \\
\text { selfing }\end{array}$} & \multicolumn{4}{|c|}{$\begin{array}{l}\text { Number of fruits } \\
\text { obtained, assigned } \\
\text { to the categories }\end{array}$} & \multirow[t]{2}{*}{$\begin{array}{l}\text { Seed content } \\
\text { in the best } \\
\text { fruit }\end{array}$} & \multirow[t]{2}{*}{$\begin{array}{l}\text { Date of } \\
\text { second } \\
\text { selfing }\end{array}$} & \multicolumn{4}{|c|}{$\begin{array}{l}\text { Number of fruits } \\
\text { obtained, assigned } \\
\text { to the categories: }\end{array}$} & \multirow[t]{2}{*}{$\begin{array}{l}\text { Seed content } \\
\text { in the best } \\
\text { fruit }\end{array}$} \\
\hline & & & $\mathrm{em}$ & $\mathrm{sm}$ & me & $\mathrm{nm}$ & & & $\mathrm{em}$ & $\mathrm{sm}$ & me & $\mathrm{nm}$ & \\
\hline \multirow{5}{*}{ Avalon } & $92-109$ & 10.06 .92 & - & 2 & 3 & 2 & $40(14 i)$ & & & & & & \\
\hline & $92-116$ & 20.07 .92 & 3 & - & - & - & & 14.08 .92 & 3 & - & - & - & \\
\hline & $92-124$ & 15.07 .92 & 4 & 1 & 1 & 1 & $115(43 i)$ & 16.08 .92 & - & - & 1 & 1 & $150(75 i)$ \\
\hline & $95-13-2$ & 27.07 .96 & 1 & 3 & - & - & $175(145 \mathrm{i})$ & & & & & & \\
\hline & $96-309 a$ & 24.07 .96 & - & - & - & 4 & $272(213 i)$ & & & & & & \\
\hline \multirow[t]{2}{*}{ Bay Minette A } & $92-127$ & & & & & & & 16.08 .92 & - & - & - & 4 & $80 n$ \\
\hline & $96-325$ & 26.07 .96 & - & - & - & 2 & $167(24 \mathrm{i})$ & & & & & & \\
\hline \multirow[t]{4}{*}{ Bellamy } & $92-131-2$ & 20.07 .92 & - & - & - & 4 & $162(14 \mathrm{i})$ & & & & & & \\
\hline & $92-131-1$ & 20.07 .92 & - & - & - & 6 & $206(24 \mathrm{i})$ & & & & & & \\
\hline & $92-137$ & 15.07 .92 & - & 1 & 1 & - & $61(53 \mathrm{i})$ & & & & & & \\
\hline & $93-335$ & 27.07 .94 & - & - & - & 2 & $196(8 \mathrm{i})$ & & & & & & \\
\hline \multirow[t]{3}{*}{ Bigbee } & $90-69-1$ & 4.08 .90 & 1 & 5 & - & - & $157(150 \mathrm{i})$ & & & & & & \\
\hline & $94-909$ & 29.07 .94 & 5 & 1 & - & - & $81(54 \mathrm{i})$ & & & & & & \\
\hline & $96-351$ & 26.07 .96 & - & - & - & 3 & $212(46 \mathrm{i})$ & & & & & & \\
\hline \multirow[t]{6}{*}{ Bolinger } & $90-70-11$ & 9.07 .90 & - & - & 4 & - & $186(170 \mathrm{i})$ & 7.08 .90 & - & - & 1 & 4 & $226(27 \mathrm{i})$ \\
\hline & $91-306 a$ & 2.07 .92 & - & - & 2 & 2 & $210(182 \mathrm{i})$ & & & & & & \\
\hline & $92-145$ & 21.07 .92 & 6 & - & 2 & 1 & $212(180 i)$ & & & & & & \\
\hline & $92-148 b$ & 15.07 .92 & - & 3 & - & 3 & 129 (124i) & & & & & & \\
\hline & $94-637$ & 28.07 .94 & - & - & - & 4 & $132(48 \mathrm{i})$ & & & & & & \\
\hline & $96-357 a$ & 22.07 .96 & - & - & - & 8 & 257 (195i) & & & & & & \\
\hline \multirow[t]{2}{*}{ Brewton } & $91-314$ & 24.07 .91 & - & 3 & 1 & - & $66 n+i$ & & & & & & \\
\hline & $92-150$ & 15.07 .92 & - & 3 & 1 & 1 & $128(40 \mathrm{i})$ & & & & & & \\
\hline Brewton $\mathrm{AB}^{\mathrm{A}}$ & $96-362$ & 23.07 .96 & - & 5 & 1 & - & $100(99 \mathrm{i})$ & & & & & & \\
\hline \multirow[t]{3}{*}{ Cantonment } & $92-158$ & & & & & & & 16.08 .92 & - & - & - & 5 & $180 n$ \\
\hline & $92-160$ & & & & & & & 20.08 .92 & - & 3 & 3 & 4 & $204 n$ \\
\hline & $96-366 b$ & 23.07 .96 & - & - & 1 & 2 & 149 (112i) & & & & & & \\
\hline Castleberry B & $92-166$ & 18.07 .92 & - & 1 & 1 & - & 160 (132i) & 13.08 .92 & 3 & - & - & - & \\
\hline & $92-170$ & 21.07 .92 & 3 & - & - & - & & & & & & & \\
\hline & $94-643$ & 28.07 .94 & - & - & - & 5 & $213(61 \mathrm{i})$ & & & & & & \\
\hline & $96-371$ & 26.07 .96 & - & - & - & 5 & $144 \mathrm{i}$ & 2.09 .96 & 1 & 1 & - & - & $26 \mathrm{i}$ \\
\hline Chastang 2 & $94-926-3$ & 2.08 .94 & - & - & - & 4 & $184(26 \mathrm{i})$ & & & & & & \\
\hline & $95-77$ & 19.07 .95 & - & - & - & 3 & $276(4 i)$ & 25.08 .95 & - & - & - & 2 & $134(24 i)$ \\
\hline & $96-374$ & 23.07 .96 & - & - & - & 4 & $250(18 \mathrm{i})$ & & & & & & \\
\hline Chastang $7 \mathrm{AB}^{\mathrm{A}}$ & $92-174-10$ & & & & & & & 16.08 .92 & - & - & - & 5 & $114 n$ \\
\hline & $92-177-1$ & 14.07 .92 & - & 1 & - & 3 & $84 n$ & & & & & & \\
\hline & $92-177-2$ & 14.07 .92 & - & 2 & 3 & - & $68 n$ & & & & & & \\
\hline & $92-179-7$ & & & & & & & 16.08 .92 & 13 & 2 & - & - & $8 \mathrm{n}$ \\
\hline & $96-378 a$ & 25.07 .96 & 6 & 2 & - & - & $25(11 \mathrm{i})$ & 25.08 .96 & - & 3 & 3 & - & $21 n$ \\
\hline & $96-378 \mathrm{c}$ & 25.07 .96 & - & 1 & - & 2 & $191 \mathrm{n}$ & & & & & & \\
\hline County Road 6 & $90-135$ & 6.08 .90 & - & - & - & 5 & $208(14 i)$ & & & & & & \\
\hline & $91-350$ & 17.07 .92 & - & 4 & - & - & $36(32 i)$ & & & & & & \\
\hline & $92-183$ & 18.07 .92 & - & - & - & 7 & $256 n$ & & & & & & \\
\hline & $92-185 b$ & & & & & & & 16.08 .92 & - & - & - & 6 & $142 n$ \\
\hline & $96-383 a$ & 23.07 .96 & - & - & - & 4 & 269 (7 i) & 2.09 .96 & 3 & - & - & - & \\
\hline Flomaton & $90-126$ & 5.08 .90 & - & - & 3 & 4 & $258 n$ & & & & & & \\
\hline & $92-190 \mathrm{~b}$ & 22.07 .92 & 3 & - & - & - & & 16.08 .92 & - & 1 & - & 3 & $230 \mathrm{n}$ \\
\hline & $92-191 a-1$ & 21.07 .92 & - & - & - & 2 & $93 n$ & 14.08 .92 & - & - & & 4 & $112 \mathrm{n}$ \\
\hline & $92-198-6$ & 23.07 .92 & 3 & - & - & - & & 16.08 .92 & 5 & - & - & 2 & $65(40 i)$ \\
\hline & $96-389 a$ & 26.07 .96 & - & - & - & 4 & $138(11 \mathrm{i})$ & & & & & & \\
\hline & $96-389 b$ & 26.07 .96 & - & - & - & 4 & $107(15 \mathrm{i})$ & & & & & & \\
\hline Frankville & $90-138$ & 6.08 .90 & - & - & - & 6 & $182(64 \mathrm{i})$ & & & & & & \\
\hline & $91-358$ & 23.07 .91 & 3 & 1 & - & - & $40(20 \mathrm{i})$ & & & & & & \\
\hline
\end{tabular}


Table 3 (continued)

\begin{tabular}{|c|c|c|c|c|c|c|c|c|c|c|c|c|c|}
\hline \multirow[t]{2}{*}{ Strain } & \multirow[t]{2}{*}{$\begin{array}{l}\text { Culture } \\
\text { number }\end{array}$} & \multirow[t]{2}{*}{$\begin{array}{l}\text { Date of } \\
\text { first } \\
\text { selfing }\end{array}$} & \multicolumn{4}{|c|}{$\begin{array}{l}\text { Number of fruits } \\
\text { obtained, assigned } \\
\text { to the categories }\end{array}$} & \multirow[t]{2}{*}{$\begin{array}{l}\text { Seed content } \\
\text { in the best } \\
\text { fruit }\end{array}$} & \multirow[t]{2}{*}{$\begin{array}{l}\text { Date of } \\
\text { second } \\
\text { selfing }\end{array}$} & \multicolumn{4}{|c|}{$\begin{array}{l}\text { Number of fruits } \\
\text { obtained, assigned } \\
\text { to the categories: }\end{array}$} & \multirow[t]{2}{*}{$\begin{array}{l}\text { Seed content } \\
\text { in the best } \\
\text { fruit }\end{array}$} \\
\hline & & & $\mathrm{em}$ & $\mathrm{sm}$ & me & $\mathrm{nm}$ & & & $\mathrm{em}$ & $\mathrm{sm}$ & me & $\mathrm{nm}$ & \\
\hline & $92-206$ & & & & & & & 17.08 .92 & - & - & 5 & - & $157(50 \mathrm{i})$ \\
\hline & $92-209 b$ & 18.07 .92 & - & 2 & - & 4 & $181(120 i)$ & & & & & & \\
\hline & $96-391 a$ & 23.07 .96 & - & - & 5 & - & $89(71 i)$ & & & & & & \\
\hline \multirow[t]{5}{*}{ Seabury Creek 1} & $90-102$ & 5.08 .90 & - & - & - & 8 & $204(40 \mathrm{i})$ & & & & & & \\
\hline & $91-398$ & & & & & & & 23.08 .91 & 1 & 1 & 5 & - & $102 n$ \\
\hline & $92-239$ & 18.07 .92 & - & - & - & 3 & $158(27 \mathrm{i})$ & & & & & & \\
\hline & $94-951-2$ & 2.07 .94 & - & - & - & 2 & $188(32 \mathrm{i})$ & 2.08 .94 & $?$ & - & 1 & - & $51(22 \mathrm{i})$ \\
\hline & $96-409$ & & & & & & & 26.08 .96 & - & - & 1 & 3 & $229(22 \mathrm{i})$ \\
\hline \multirow[t]{4}{*}{ Seabury Creek 2} & $91-401$ & & & & & & & 23.08 .91 & - & - & 3 & 3 & $184(8 \mathrm{i})$ \\
\hline & $92-251$ & 18.07 .92 & - & - & - & 5 & $174 n$ & & & & & & \\
\hline & $96-413$ & 30.07 .96 & - & - & - & 2 & $181 \mathrm{n}$ & & & & & & \\
\hline & $96-415 b$ & 26.07 .96 & - & - & 3 & 3 & 208 (3i) & & & & & & \\
\hline \multirow[t]{7}{*}{ Sims Chapel } & $90-134$ & 10.08 .90 & - & - & - & 3 & 194 (120i) & & & & & & \\
\hline & $91-420$ & & & & & & & 23.08 .91 & - & - & 3 & 2 & $170(17 \mathrm{i})$ \\
\hline & $92-269$ & 22.07 .92 & - & - & 5 & - & $88 \mathrm{n}+\mathbf{i}$ & & & & & & \\
\hline & $92-272-3$ & 22.07 .92 & - & - & 1 & 1 & $1] 7(11 \mathrm{i})$ & & & & & & \\
\hline & $92-272-9$ & & & & & & & 18.08 .92 & - & 2 & 3 & - & $64 n+i$ \\
\hline & $92-273 a$ & 15.07 .92 & 3 & - & $-m$ & - & & 18.08 .92 & - & 3 & - & - & $194 n+i$ \\
\hline & $96-425$ & & & & & & & 26.08 .96 & - & - & 1 & 2 & $158(4 i)$ \\
\hline \multirow{5}{*}{ Stockton 1} & $91-426-5$ & 23.07 .91 & - & - & 1 & 3 & $304(2 \mathrm{i})$ & & & & & & \\
\hline & $92-275 b$ & 19.07 .62 & - & - & - & 6 & $278(2 \mathrm{i})$ & & & & & & \\
\hline & $92-278$ & 22.07 .92 & - & 5 & - & - & $10 n$ & & & & & & \\
\hline & $96-430 \mathrm{a}$ & 27.07 .96 & - & - & 3 & - & $156(38 \mathrm{i})$ & & & & & & \\
\hline & $96-432$ & & & & & & & 3.09 .96 & - & - & - & 3 & 165 (154i) \\
\hline \multirow[t]{4}{*}{ Stockton 2} & $89-667$ & 27.07 .89 & - & - & - & 6 & $12 n$ & & & & & & \\
\hline & $90-143$ & 8.08 .90 & 1 & - & 1 & 3 & $250(168 \mathrm{i})$ & & & & & & \\
\hline & $92-283$ & & & & & & & 18.08 .92 & - & 3 & - & - & $35 n$ \\
\hline & $93-489$ & & & & & & & 24.08 .93 & 6 & 1 & - & - & $11(6 i)$ \\
\hline \multirow[t]{9}{*}{ Stockton derived } & $90-111-5$ & 5.08 .90 & - & - & 2 & 2 & $208(138 \mathrm{i})$ & & & & & & \\
\hline & $90-111-6$ & 5.08 .90 & - & 2 & 3 & 2 & $167 n+i$ & & & & & & \\
\hline & $91-363-17$ & 25.07 .91 & 10 & - & - & - & & 22.08 .91 & 5 & - & - & 3 & $57(2 \mathrm{i})$ \\
\hline & $91-364-8$ & 18.07 .91 & - & 2 & - & - & $130 n+i$ & 22.08 .91 & - & - & 3 & - & $134(123 i)$ \\
\hline & $92-211 b-1$ & 18.07 .92 & - & 3 & 1 & - & $183 n+i$ & & & & & & \\
\hline & $92-211 b-4$ & 20.07 .92 & - & - & 1 & 3 & $173(95 \mathrm{i})$ & & & & & & \\
\hline & $92-214$ & 18.07 .92 & - & 2 & - & - & $20 n$ & 17.08 .92 & - & - & - & 4 & $224 n+i$ \\
\hline & $92-215$ & 18.07 .92 & 3 & - & - & - & & 17.08 .92 & 2 & - & 2 & - & $153(90 \mathrm{i})$ \\
\hline & $96-399$ & 24.07 .96 & - & - & - & 7 & $245(50 i)$ & & & & & & \\
\hline \multirow[t]{5}{*}{ Tuscaloosa } & $90-108$ & 31.07 .90 & - & - & - & 5 & $268(66 \mathrm{i})$ & 5.08 .90 & - & 2 & 2 & 3 & $198(80 \mathrm{i})$ \\
\hline & $91-440-1$ & 20.07 .91 & 1 & 3 & 2 & - & $74 n$ & & & & & & \\
\hline & $92-287$ & 19.07 .92 & - & - & 1 & 3 & $160 n$ & 18.08 .92 & - & - & - & 6 & not counted \\
\hline & $92-291$ & & & & & & & 18.08 .92 & - & - & - & 3 & $107 \mathrm{n}$ \\
\hline & $96-441-1$ & 28.07 .96 & - & - & - & 3 & $320(20 \mathrm{i})$ & & & & & & \\
\hline \multirow[t]{4}{*}{ York } & $89-662$ & 4.08 .89 & - & 3 & 4 & 9 & $160 n$ & & & & & & \\
\hline & $91-447$ & 19.07 .92 & - & - & - & 5 & $202(10 \mathrm{i})$ & 24.08 .91 & 3 & - & - & - & \\
\hline & $91-448$ & & & & & & & 24.08 .91 & - & - & - & 4 & $246(6 i)$ \\
\hline & $93-502$ & & & & & & & 26.08 .93 & - & - & 3 & 2 & $322(104 i)$ \\
\hline
\end{tabular}

are fully incompatible, but this would not have been an obstacle to the formation of BC-IV (O. parviflora), since the CC-IV parent could act as the female as well as the male parent. Assuming that the $\mathrm{B}$ complex had already lost its ability to harmonize with plastome IV in the male gametophyte, the hybrid would have been immediately semi-heterogamous. This remains to be supported by experimental evidence.

An alternative to the view that plastome IV is the ancestral type for the subsection is that a more 
W. Stubbe and E. Steiner: Genome-plastome incompatibility in Oenothera

Table 4. Progeny obtained from selfed Oenothera AB-IV plants

\begin{tabular}{|c|c|c|c|c|c|c|c|c|c|}
\hline \multirow[t]{2}{*}{ Strain } & \multirow{2}{*}{$\begin{array}{l}\text { Culture } \\
\text { number } \\
\text { of parent }\end{array}$} & \multirow[t]{2}{*}{$\begin{array}{l}\text { Date of } \\
\text { selfing }\end{array}$} & \multirow[t]{2}{*}{$\begin{array}{l}\text { Seeds } \\
\text { sown }\end{array}$} & \multicolumn{2}{|c|}{$\begin{array}{l}\text { Progeny } \\
\text { identified as }\end{array}$} & \multirow{2}{*}{$\begin{array}{l}\text { Germlings } \\
\text { died unid- } \\
\text { entified }\end{array}$} & \multirow{2}{*}{$\begin{array}{l}\text { Seeds not } \\
\text { germinated } \\
\text { with embryo }\end{array}$} & \multirow[t]{2}{*}{$\begin{array}{l}\text { Empty } \\
\text { seeds }\end{array}$} & \multirow{2}{*}{$\begin{array}{l}\text { Culture } \\
\text { number } \\
\text { (grown) }\end{array}$} \\
\hline & & & & $\mathrm{AB}$ & $\mathrm{BB}$ & & & & \\
\hline \multirow[t]{4}{*}{ Avalon } & $90-120 b$ & 5.08 & 64 & 5 & - & 5 & 1 & 53 & $92-115$ \\
\hline & $90-121-1$ & 5.08 & 66 & 6 & - & - & - & 60 & $92-124$ \\
\hline & $92-109$ & 10.06 & 26 & 1 & - & - & - & 25 & $93-318$ \\
\hline & $92-124-3$ & 15.07 & 30 & 5 & - & - & - & 25 & $94-623$ \\
\hline \multirow[t]{2}{*}{ Bay Minette A } & $91-282$ & 21.07 & 31 & 1 & - & - & - & 30 & $92-128$ \\
\hline & $92-127$ & 16.08 & 80 & - & - & - & - & 80 & $94-625$ \\
\hline \multirow[t]{3}{*}{ Bellamy } & $91-290-4$ & 20.07 & 60 & 18 & 19 & 1 & - & 22 & $92-131$ \\
\hline & $91-293-1$ & 19.07 & 40 & 3 & 3 & - & - & 34 & $92-133$ \\
\hline & $89-635$ & 1.08 & 109 & 6 & - & 6 & 5 & 92 & $93-335$ \\
\hline \multirow[t]{3}{*}{ Bigbee } & $90-69-1$ & 20.07 & 7 & - & - & - & - & 7 & $91-301$ \\
\hline & $91-303-1$ & 19.08 & 27 & - & - & - & - & 27 & $92-147 b$ \\
\hline & $93-347$ & 5.07 & 48 & 1 & - & - & - & 47 & $94-909$ \\
\hline \multirow[t]{4}{*}{ Bolinger } & $91-307$ & 20.07 & 66 & 2 & - & - & - & 64 & $92-148 b$ \\
\hline & $92-145$ & 21.07 & 42 & - & - & - & - & 42 & $94-634$ \\
\hline & $92-148 b$ & 15.07 & 20 & - & - & - & - & 20 & $94-636$ \\
\hline & $91-306 a$ & 2.07 & 19 & 5 & - & 1 & - & 13 & $94-637$ \\
\hline \multirow{2}{*}{ Brewton } & $91-310-2$ & 21.08. & 80 & 3 & - & - & 6 & 71 & $92-151 b$ \\
\hline & $91-314-4$ & 24.07 & 78 & - & - & 1 & - & 77 & $92-154 b$ \\
\hline \multirow[t]{3}{*}{ Cantonment } & $92-160$ & 20.08 & 60 & 2 & - & - & 1 & 57 & $93-379$ \\
\hline & $92-158$ & 16.08 & 75 & 2 & - & - & 2 & 71 & $94-641$ \\
\hline & $92-160$ & 20.08 & 30 & 7 & - & 1 & - & 22 & $94-642$ \\
\hline Castleberry B & $92-166-1$ & 18.07 & 50 & 1 & - & 1 & - & 48 & $94-643$ \\
\hline Chastang 2 & $94-926-3$ & 2.08 & 60 & 1 & 1 & 5 & 2 & 51 & $95-76$ \\
\hline \multirow[t]{2}{*}{ Chastang $7^{*}$} & $92-174-10$ & 16.08 & 28 & 5 & 2 & 1 & 2 & 18 & $94-647$ \\
\hline & $92-179-7$ & 16.08. & 13 & 1 & - & - & 2 & 10 & $94-651$ \\
\hline \multirow[t]{5}{*}{ County Road 6} & $90-135-4$ & 6.08 & 54 & 1 & - & - & 1 & 52 & $92-187$ \\
\hline & $91-350-1$ & 17.07 & 30 & 3 & - & - & - & 27 & $94-652$ \\
\hline & $92-183-4$ & 18.07 & 30 & 1 & - & 4 & - & 25 & $94-653$ \\
\hline & $92-185 b$ & 16.08 & 90 & 1 & - & 1 & - & 88 & $94-654$ \\
\hline & $92-187$ & 18.07. & 73 & 1 & - & 2 & - & 70 & $94-655$ \\
\hline Flomaton & $90-126-1$ & 5.08 & 43 & 10 & 1 & - & - & 32 & $91-353$ \\
\hline & $89-648$ & 26.07 & 30 & 15 & - & - & - & 15 & $92-191 \mathrm{a}$ \\
\hline & $92-190 b$ & 22.07 & 30 & 3 & - & 2 & - & 25 & $94-656$ \\
\hline & $92-191 a-0$ & 21.07 & 30 & 1 & 6 & - & 1 & 22 & $94-658$ \\
\hline & $92-191 a-1$ & 21.07 & 30 & 7 & 5 & - & - & 18 & $94-659$ \\
\hline & $92-191 \mathrm{a}-1$ & 14.08 & 30 & 5 & 3 & - & - & 22 & $94-660$ \\
\hline & $92-191 a-3$ & 14.08 & 34 & 7 & - & - & - & 27 & $94-661$ \\
\hline & $92-194-1$ & 16.08 & 32 & 14 & - & - & - & 18 & $94-662$ \\
\hline & $92-194-2$ & 18.07 & 35 & 4 & - & - & 1 & 30 & $94-663$ \\
\hline & $92-195-4$ & 18.07. & 30 & 5 & - & - & - & 25 & $94-664$ \\
\hline & $92-198-6$ & 16.08 & 34 & 1 & - & - & - & 33 & $94-665$ \\
\hline & $92-202-1$ & 2.07 & 35 & - & - & 1 & 1 & 33 & $94-666$ \\
\hline & $92-191 a-1$ & 14.08 & 60 & 10 & 5 & 1 & - & 44 & $95-94$ \\
\hline Frankville & $90-138-8$ & 6.08 & 80 & 2 & - & - & - & 78 & $92-206$ \\
\hline & $91-358$ & 23.07 & 42 & 7 & 1 & - & - & 34 & $93-434$ \\
\hline & $92-206$ & 17.08 & 39 & 1 & - & 1 & - & 37 & $94-667$ \\
\hline & $92-209 b$ & 18.07 & 30 & 2 & - & - & - & 28 & $94-669$ \\
\hline Seabury Creek 1 & $91-393-1$ & 23.08 & 25 & 4 & - & 1 & 1 & 19 & $92-240$ \\
\hline & $91-398$ & 23.08 & 60 & - & - & - & 1 & 59 & $92-243$ \\
\hline & $90-103-2$ & 5.08 & 40 & 4 & - & - & 3 & 33 & $92-247 b$ \\
\hline & $91-393-3$ & 23.08 & 94 & 2 & - & 5 & - & 83 & $\begin{array}{l}93-464 \\
\text { (contd.) }\end{array}$ \\
\hline
\end{tabular}


Table 4 (continued)

\begin{tabular}{|c|c|c|c|c|c|c|c|c|c|}
\hline \multirow[t]{2}{*}{ Strain } & \multirow{2}{*}{$\begin{array}{l}\text { Culture } \\
\text { number } \\
\text { of parent }\end{array}$} & \multirow[t]{2}{*}{$\begin{array}{l}\text { Date of } \\
\text { selfing }\end{array}$} & \multirow[t]{2}{*}{$\begin{array}{l}\text { Seeds } \\
\text { sown }\end{array}$} & \multicolumn{2}{|c|}{$\begin{array}{l}\text { Progeny } \\
\text { identified as }\end{array}$} & \multirow{2}{*}{$\begin{array}{l}\text { Germlings } \\
\text { died unid- } \\
\text { entified }\end{array}$} & \multirow{2}{*}{$\begin{array}{l}\text { Seeds not } \\
\text { germinated } \\
\text { with embryo }\end{array}$} & \multirow[t]{2}{*}{$\begin{array}{l}\text { Empty } \\
\text { seeds }\end{array}$} & \multirow{2}{*}{$\begin{array}{l}\text { Culture } \\
\text { number } \\
\text { (grown) }\end{array}$} \\
\hline & & & & $\mathrm{AB}$ & $\mathrm{BB}$ & & & & \\
\hline & $92-239$ & 18.07 & 144 & 1 & - & - & - & 143 & $94-682$ \\
\hline \multirow[t]{2}{*}{ Seabury Creek 2} & $91-401$ & 23.08 & 40 & - & - & - & 4 & 36 & $92-250 b$ \\
\hline & $92-251-1$ & 18.07 & 29 & 1 & - & - & - & 27 & $94-686$ \\
\hline \multirow[t]{6}{*}{ Sims Chapel } & $90-134-1$ & 10.08 & 50 & 18 & - & 4 & - & 28 & $91-420$ \\
\hline & $92-269$ & 22.07 & 80 & 3 & 1 & 17 & - & 21 & $94-695$ \\
\hline & $92-271 a$ & 17.08 & 28 & 3 & - & - & - & 25 & $94-696$ \\
\hline & $92-272-3$ & 22.07 & 28 & 4 & - & 1 & - & 23 & $94-697$ \\
\hline & $92-272-9$ & 18.08 & 28 & 2 & - & - & 1 & 25 & $94-698$ \\
\hline & $92-273 a$ & 18.08 & 40 & 9 & 1 & 1 & 2 & 27 & $94-699$ \\
\hline \multirow[t]{3}{*}{ Stockton 1} & $91-426-5$ & 23.07 & 60 & 3 & - & 2 & - & 55 & $92-275 b$ \\
\hline & $92-275 b-1$ & 19.07. & 50 & 6 & - & - & - & 44 & $93-484$ \\
\hline & $92-278$ & 23.07 & 31 & - & - & - & - & 31 & $94-700$ \\
\hline \multirow[t]{3}{*}{ Stockton 2} & $89-667$ & 27.07 & 32 & - & - & - & - & 32 & $91-433$ \\
\hline & $90-143-1$ & 8.08 & 60 & 4 & - & - & - & 56 & $91-434$ \\
\hline & $92-283$ & 18.08 & 44 & - & - & - & - & 44 & $94-702$ \\
\hline \multirow[t]{12}{*}{ Stockton derived } & $91-364-4$ & 20.07 & 50 & 8 & - & 1 & 4 & 37 & $92-2111 b$ \\
\hline & $90-111-5$ & 5.08 & 80 & 4 & - & 1 & 3 & 72 & $92-212$ \\
\hline & $91-363-17$ & 22.08 & 77 & 16 & 8 & 5 & 10 & 38 & $92-214$ \\
\hline & $91-364-8$ & 22.08 & 37 & 2 & - & - & 1 & 34 & $92-215$ \\
\hline & $90-111-0$ & 10.08 & 54 & 11 & - & - & 5 & 38 & $92-219 b$ \\
\hline & $90-111-6$ & 5.08 & 68 & 3 & 1 & 4 & 35 & 25 & $92-442$ \\
\hline & $92-211 b-1$ & 18.07 & 36 & 3 & - & 2 & - & 31 & $94-670$ \\
\hline & $92-211 b-4$ & 20.07 & 30 & 4 & - & 3 & - & 23 & $94-671$ \\
\hline & $92-212-4$ & 22.07 & 124 & - & - & 5 & 3 & 116 & $94-672$ \\
\hline & $92-214-12$ & 18.07 & 26 & - & 15 & - & 7 & 4 & $94-676$ \\
\hline & $92-214-12$ & 17.08 & 30 & - & 26 & - & - & 4 & $94-677$ \\
\hline & $92-215$ & 17.08 & 30 & 7 & - & 4 & - & 19 & $94-679$ \\
\hline \multirow[t]{6}{*}{ Tuscaloosa } & $90-108-1$ & 31.07 & 61 & 7 & 4 & - & - & 50 & $91-440$ \\
\hline & $90-108$ & 5.08 & 58 & 9 & 12 & 3 & - & 34 & $92-287$ \\
\hline & $92-287-4$ & 19.07 & 30 & - & 12 & - & - & 18 & $94-704$ \\
\hline & $92-287$ & 18.08 & 30 & 3 & 1 & - & - & 26 & $94-705$ \\
\hline & $92-291$ & 18.08 & 30 & 4 & 5 & 1 & - & 20 & $94-710$ \\
\hline & $91-440$ & 20.07 & 40 & 11 & 10 & 1 & - & 18 & $94-792$ \\
\hline \multirow[t]{2}{*}{ York } & $91-448$ & 24.08 & 40 & 7 & - & 1 & 1 & 31 & $92-297$ \\
\hline & $91-447$ & 19.07. & 90 & 5 & 1 & 5 & - & 79 & 94-976 \\
\hline
\end{tabular}

* The genotype of this strain is $\mathrm{AB}^{\mathrm{A}}$

primitive precursor of plastome IV existed which is now extinct. Such a plastome type would have exhibited a slow multiplication rate which was later replaced by more rapidly multiplying ones.

The results of the current investigation make it doubtful that the precursor of the extant $O$. grandiflora possessed plastome IV because of the now established incompatibility between the B genotype and plastome IV. Moreover, similar findings exist with the A genotype although to a limited degree (Stubbe 1963,
Stubbe et al. 1978). Therefore, we favor the hypothesis that a precursor existed which tolerated the differentiation of the ancestral genome into three different genomes $\mathrm{A}, \mathrm{B}$, and $\mathrm{C}$, and from which the three plastomes II, III, IV were derived later. A diagram of this evolutionary scheme is shown in Fig. 4. More detailed information is to be expected from molecular investigations on the plastome. A recent paper (Sears et al. 1996) describes comparisons of repetitive sequences of one of the putative cpDNA replication 
Table 5. Examples of seed set obtained by selfing of Oenothera BB-IV plants. Abbreviations: $n$ normal seeds, $i$ imperfectly developed seeds, quota in parenthesis, em empty fruits, $s m$ small fruits, me medium-sized fruits, $n m$ normal fruits

\begin{tabular}{|c|c|c|c|c|c|c|c|c|c|c|c|c|c|}
\hline \multirow[t]{2}{*}{ Strain } & \multirow[t]{2}{*}{$\begin{array}{l}\text { Culture } \\
\text { number }\end{array}$} & \multirow[t]{2}{*}{$\begin{array}{l}\text { Date of } \\
\text { first } \\
\text { selfing }\end{array}$} & \multicolumn{4}{|c|}{$\begin{array}{l}\text { Number of fruits } \\
\text { obtained, assigned } \\
\text { to the categories: }\end{array}$} & \multirow[t]{2}{*}{$\begin{array}{l}\text { Seed content } \\
\text { in the best } \\
\text { fruit }\end{array}$} & \multirow[t]{2}{*}{$\begin{array}{l}\text { Date of } \\
\text { second } \\
\text { selfing }\end{array}$} & \multicolumn{4}{|c|}{$\begin{array}{l}\text { Number of fruits } \\
\text { obtained, assigned } \\
\text { to the categories: }\end{array}$} & \multirow[t]{2}{*}{$\begin{array}{l}\text { Seed content } \\
\text { in the best } \\
\text { fruit }\end{array}$} \\
\hline & & & $\mathrm{em}$ & $\mathrm{sm}$ & me & $\mathrm{nm}$ & & & $\mathrm{em}$ & $\mathrm{sm}$ & me & $\mathrm{nm}$ & \\
\hline Avalon & $96-460$ & 28.07 .96 & - & - & - & 5 & $215 \mathrm{i}$ & 4.09 .96 & 2 & 2 & - & - & $104(80 \mathrm{i})$ \\
\hline Bay Minette A & $96-328$ & 28.07 .96 & - & - & 1 & 1 & $181 \mathrm{i}$ & 23.08 .96 & 3 & 1 & 1 & - & $61 n$ \\
\hline \multirow[t]{4}{*}{ Bellamy } & $93-337$ & 6.07 .96 & - & - & 1 & 4 & $172(75 i)$ & 1.08 .93 & - & - & - & 6 & $101(50 \mathrm{i})$ \\
\hline & $94-907$ & 28.07 .94 & - & - & - & 3 & $143(78 i)$ & 10.08 .93 & - & - & - & 4 & $172(18 \mathrm{i})$ \\
\hline & $96-343 a$ & 31.07 .96 & - & - & - & 2 & $127(109 \mathrm{i})$ & 23.08 .96 & - & 1 & 1 & - & $140(136 \mathrm{i})$ \\
\hline & $96-346 a$ & 29.06 .96 & 3 & 1 & - & - & $16(13 i)$ & 24.07 .96 & - & - & - & 3 & $122(37 i)$ \\
\hline \multirow[t]{10}{*}{ Bigbee } & $93-347$ & 5.07 .93 & 1 & - & 2 & - & $97 \mathrm{i}$ & & & & & & \\
\hline & $93-350-1$ & 5.07 .93 & - & - & - & 5 & $205(48 i)$ & 1.08 .93 & - & - & - & 5 & $352(210 i)$ \\
\hline & $93-350-2$ & 7.07 .93 & - & - & - & 4 & $167(80 \mathrm{i})$ & 2.08 .93 & - & - & - & 3 & $330(42 i)$ \\
\hline & $94-909-4$ & & & & & & & 10.08 .94 & - & - & - & 1 & $206 \mathrm{i}$ \\
\hline & $95-49$ & 17.07 .95 & - & - & 1 & - & $236 \mathrm{i}$ & 22.08 .95 & - & - & 3 & - & $104 \mathrm{i}$ \\
\hline & $96-349 b-1$ & 22.07 .96 & 3 & - & - & - & & 23.08 .96 & 1 & 2 & - & - & $40 \mathrm{i}$ \\
\hline & $96-349 b-2$ & 25.07 .96 & - & 3 & 2 & - & $65 \mathrm{i}$ & & & & & & \\
\hline & $96-353 a-4$ & 25.07 .96 & - & 3 & 2 & - & $19(8 \mathrm{i})$ & 23.08 .96 & - & - & 1 & - & $83 \mathbf{i}$ \\
\hline & $96-354 a$ & 25.07 .96 & - & 2 & 3 & - & 25 (15i) & 25.08 .96 & - & - & 2 & - & $177 i$ \\
\hline & $96-355 a$ & 25.07 .96 & - & - & - & 9 & $263 \mathrm{i}$ & 25.09 .96 & - & 3 & - & - & $42 \mathrm{i}$ \\
\hline \multirow[t]{4}{*}{ Bolinger } & $90-70$ & 4.08 .90 & - & - & - & 8 & $242(239 i)$ & & & & & & \\
\hline & $92-145$ & & & & & & & 2.10 .92 & - & 3 & - & & $95 \mathrm{i}$ \\
\hline & $95-56-2$ & 19.07 .95 & - & - & - & 4 & $284(262 i)$ & & & & & & \\
\hline & $96-357 b$ & 25.07 .96 & - & 1 & 4 & 1 & $188(176 \mathrm{i})$ & & & & & & \\
\hline \multirow[t]{3}{*}{ Brewton } & $92-150$ & 2.07 .92 & - & - & - & 4 & $242(239 \mathrm{i})$ & 16.08 .92 & - & 1 & 2 & - & $107(42 i)$ \\
\hline & $96-361 b$ & & & & & & & 23.08 .96 & - & 2 & - & - & $96(52 i)$ \\
\hline & $96-364$ & 29.07 .96 & 3 & 1 & - & - & $34 \mathrm{i}$ & 28.08 .96 & - & - & 5 & - & $68 \mathrm{i}$ \\
\hline \multirow{5}{*}{ Cantonment } & $96-366 a$ & 25.07 .96 & - & - & - & 5 & $282 \mathrm{i}$ & 28.08 .96 & - & - & - & 4 & $252(12 i)$ \\
\hline & $96-368 \mathrm{a}-1$ & 25.07 .96 & - & - & - & 4 & 235 (185i) & & & & & & \\
\hline & $96-368 a-2$ & 25.07 .96 & - & - & - & 3 & $117(834 i)$ & & & & & & \\
\hline & $96-368 b-1$ & 25.07 .96 & - & - & - & 4 & $264 i$ & & & & & & \\
\hline & $96-369$ & & & & & & & 23.08 .96 & - & - & - & 3 & $300(34 i)$ \\
\hline \multirow[t]{3}{*}{ Castleberry B } & $93-396$ & 1.08 .93 & - & 3 & - & - & $27 n+i$ & & & & & & \\
\hline & $94-922$ & & & & & & & 2.09 .94 & - & 2 & - & - & $102(50 i)$ \\
\hline & $96-372$ & 25.07 .96 & 3 & - & - & - & & 4.09 .96 & 3 & - & - & - & \\
\hline Chastang 2 & $96-375 b$ & & & & & & & 25.08 .96 & - & 1 & 1 & 4 & $112(4 i)$ \\
\hline Chastang $7^{*}$ & $92-171 \mathrm{~b}$ & & & & & & & 4.10 .92 & - & - & 5 & - & $114(20 \mathrm{i})$ \\
\hline & $96-387 c$ & 25.07 .96 & - & - & 3 & 4 & $146(9 \mathrm{i})$ & 24.08 .96 & - & - & 4 & - & $72(35 \mathrm{i})$ \\
\hline Flomaton & $93-427-1$ & 16.09 .93 & 6 & 1 & - & - & $62 \mathrm{i}$ & 5.10 .93 & 3 & - & 1 & 1 & $99(25 \mathrm{i})$ \\
\hline & $93-427-3$ & 22.08 .93 & - & - & - & 6 & $310(96 \mathrm{i})$ & 18.09 .93 & - & - & - & 1 & $292(264 i)$ \\
\hline & $93-429-1$ & 23.08 .93 & - & - & 3 & - & $142(130 i)$ & 18.09 .93 & 9 & - & - & - & \\
\hline & $93-429-2$ & & & & & & & 17.09 .93 & 1 & 2 & 2 & - & $75(26 i)$ \\
\hline & $94-935$ & 3.08 .94 & - & - & 3 & - & $60 \mathrm{i}$ & 5.09 .93 & - & - & 3 & - & $70 i$ \\
\hline & $96-385$ & & & & & & & 25.08 .96 & - & - & 1 & 2 & $180(30 i)$ \\
\hline & $96-386 b$ & 25.07 .96 & 2 & - & 1 & - & $51(19 i)$ & & & & & & \\
\hline Frankville & $92-209 b$ & 2.07 .92 & - & 3 & - & - & $75(23 i)$ & 22.07 .92 & - & - & 7 & - & $182 n+i$ \\
\hline & $93-437$ & 6.07 .93 & 1 & - & 1 & 3 & $100(19 i)$ & 2.08 .93 & - & - & - & 5 & $320(86 i)$ \\
\hline & $94-939$ & & & & & & & 10.08 .94 & - & - & 2 & 6 & $207(204 i)$ \\
\hline Seabury Creek 1 & $94-951$ & 2.07 .94 & - & - & - & 2 & $188(40 i)$ & & & & & & \\
\hline & $96-410 \mathrm{a}$ & 29.07 .96 & - & - & - & 3 & $194(11 i)$ & 25.08 .96 & - & - & 4 & - & $161(7 i)$ \\
\hline Seabury Creek 2 & $92-260-1$ & 14.07 .92 & - & - & - & 5 & $202 i$ & & & & & & \\
\hline & $93-469$ & 7.07 .93 & - & - & - & 3 & $179(124 \mathrm{i})$ & 1.08 .93 & - & - & - & 5 & $308(60 i)$ \\
\hline & $94-958$ & & & & & & & 5.09 .94 & - & - & 3 & - & $67(5 i)$ \\
\hline & $95-115$ & 18.07 .95 & - & - & - & 2 & $173(159 i)$ & 25.08 .95 & - & - & 3 & - & $46 i$ \\
\hline & $96-114$ & 26.07 .96 & - & - & - & 4 & $181(47 \mathrm{i})$ & & & & & & \\
\hline & $96-417 \mathrm{a}$ & & & & & & & 26.08 .96 & - & 4 & - & - & $7(1 \mathrm{i})$ \\
\hline Sims Chapel & $92-270$ & & & & & & & 20.08 .92 & - & - & - & 2 & $186(152 i)$ \\
\hline & $92-272$ & 14.07 .92 & - & - & - & 3 & $192 n$ & & & & & & \\
\hline
\end{tabular}


Table 5 (continued)

\begin{tabular}{|c|c|c|c|c|c|c|c|c|c|c|c|c|c|}
\hline \multirow[t]{2}{*}{ Strain } & \multirow[t]{2}{*}{$\begin{array}{l}\text { Culture } \\
\text { number }\end{array}$} & \multirow[t]{2}{*}{$\begin{array}{l}\text { Date of } \\
\text { first } \\
\text { selfing }\end{array}$} & \multicolumn{4}{|c|}{$\begin{array}{l}\text { Number of fruits } \\
\text { obtained, assigned } \\
\text { to the categories: }\end{array}$} & \multirow[t]{2}{*}{$\begin{array}{l}\text { Seed content } \\
\text { in the best } \\
\text { fruit }\end{array}$} & \multirow[t]{2}{*}{$\begin{array}{l}\text { Date of } \\
\text { second } \\
\text { selfing }\end{array}$} & \multicolumn{4}{|c|}{$\begin{array}{l}\text { Number of fruits } \\
\text { obtained, assigned } \\
\text { to the categories: }\end{array}$} & \multirow[t]{2}{*}{$\begin{array}{l}\text { Seed content } \\
\text { in the best } \\
\text { fruit }\end{array}$} \\
\hline & & & $\mathrm{em}$ & $\mathrm{sm}$ & me & $\mathrm{nm}$ & & & $\mathrm{em}$ & $\mathrm{sm}$ & me & $\mathrm{nm}$ & \\
\hline & $93-478$ & 17.09 .93 & - & - & - & 3 & $236(6 i)$ & 27.10 .93 & - & - & 3 & - & $105(37 \mathrm{i})$ \\
\hline & $95-120$ & 27.08 .95 & 4 & - & 1 & - & 43 (13i) & 23.09 .95 & 2 & - & 1 & - & $36(14 \mathrm{i})$ \\
\hline & $95-126$ & & & & & & & 22.08 .95 & - & - & - & 2 & $382(370 \mathrm{i})$ \\
\hline & $96-425$ & & & & & & & 26.08 .96 & 2 & - & 3 & - & $85(8 \mathrm{i})$ \\
\hline & $96-427$ & & & & & & & 26.08 .96 & - & - & 5 & - & $137(13 i)$ \\
\hline & $96-429 a$ & & & & & & & 5.09 .96 & - & 2 & 3 & - & $73 n$ \\
\hline \multirow{2}{*}{ Stockton 1} & $92-277$ & 1.07 .92 & - & - & - & 4 & $275(263 \mathrm{i})$ & & & & & & \\
\hline & $95-130$ & 28.08 .95 & - & - & - & 2 & 309 (300i) & 14.10 .95 & - & 1 & 2 & 1 & $245 \mathrm{i}$ \\
\hline \multirow[t]{3}{*}{ Stockton 2} & $92-285 b$ & 15.07 .92 & 2 & 2 & - & - & $58(57 i)$ & & & & & & \\
\hline & $96-436 a$ & & & & & & & 26.08 .96 & - & 1 & 4 & - & $83 \mathrm{i}$ \\
\hline & $96-439$ & 28.07 .96 & 4 & - & - & - & & 26.08 .96 & - & - & 3 & - & $120 \mathrm{i}$ \\
\hline \multirow[t]{9}{*}{ Stockton derived } & $91-360$ & & & & & & & 22.08 .91 & - & - & 6 & - & $128 n+i$ \\
\hline & $92-213-2$ & & & & & & & 18.08 .92 & - & - & - & 5 & $163(20 \mathrm{i})$ \\
\hline & $92-213-3$ & & & & & & & 18.08 .92 & - & - & 1 & 1 & $182 \mathrm{n}$ \\
\hline & $93-440$ & 1.08 .93 & - & - & - & 4 & $118(6 \mathrm{i})$ & 23.08 .93 & - & 2 & 3 & - & $89(61 \mathrm{i})$ \\
\hline & $93-440$ & 3.08 .93 & - & - & - & 4 & $306(136 \mathrm{i})$ & 26.08 .93 & - & - & - & 6 & $146(13 i)$ \\
\hline & $94-677$ & & & & & & & 5.09 .94 & - & - & 2 & 3 & $112(58 \mathrm{i})$ \\
\hline & $96-395 a$ & & & & & & & 25.08 .96 & - & - & 3 & 3 & $261(37 i)$ \\
\hline & $96-398$ & 27.07 .96 & 1 & - & 1 & - & $13(2 \mathrm{i})$ & 25.08 .96 & 3 & 1 & 8 & - & $232(40 i)$ \\
\hline & $96-400 \mathrm{a}$ & 26.07 .96 & 4 & - & - & - & & 28.08 .96 & - & - & 6 & - & $259(57 \mathrm{i})$ \\
\hline \multirow[t]{9}{*}{ Tuscaloosa } & $92-287$ & & & & & & & 19.08 .92 & 3 & - & 1 & 2 & $206 n$ \\
\hline & $92-290-1$ & & & & & & & 19.08 .92 & - & - & - & 2 & $230 n+i$ \\
\hline & $92-290-2$ & & & & & & & 19.08 .92 & - & - & - & 4 & $140 n+i$ \\
\hline & $93-496-1$ & 2.08 .93 & - & - & - & 3 & $276(114 i)$ & 20.08 .93 & - & - & - & 5 & $208(94 i)$ \\
\hline & $93-496-3$ & 2.08 .93 & - & - & - & 4 & $186(32 \mathrm{i})$ & 20.08 .93 & - & - & - & 5 & 212 (90i) \\
\hline & $94-709$ & 2.07 .94 & - & - & - & 1 & $73 n$ & 28.07 .94 & - & - & - & 4 & $114(5 i)$ \\
\hline & $95-134$ & 18.07 .95 & - & - & - & 4 & $252(146 \mathrm{i})$ & 28.08 .95 & - & - & 1 & 4 & $189(165 \mathrm{i})$ \\
\hline & $96-441-3$ & 28.07 .96 & - & - & - & 3 & $186(77 \mathrm{i})$ & 27.08 .96 & 1 & - & 3 & - & $164 \mathrm{i}$ \\
\hline & $96-441-4$ & & & & & & & 27.08 .96 & - & - & 1 & 5 & $240(119 \mathrm{i})$ \\
\hline \multirow[t]{7}{*}{ York } & $92-297$ & & & & & & & 18.08 .92 & - & - & - & 7 & $198(14 \mathrm{i})$ \\
\hline & $93-499-2$ & 3.08 .93 & - & - & - & 3 & $302(228 \mathrm{i})$ & 27.08 .93 & - & - & - & 3 & $362(336 i)$ \\
\hline & $93-501-1$ & 6.07 .93 & - & - & - & 7 & $167 \mathrm{n}$ & & & & & & \\
\hline & $93-501-2$ & 2.08 .93 & - & - & - & 3 & $300 n$ & 27.08 .93 & - & - & - & 5 & $240(148 \mathrm{i})$ \\
\hline & $96-445 a$ & & & & & & & 4.09 .96 & - & - & - & 6 & $195(109 \mathrm{i})$ \\
\hline & $96-448$ & 28.07 .96 & - & - & - & 3 & $381(114 \mathrm{i})$ & & & & & & \\
\hline & $96-452$ & 28.07 .96 & - & - & - & 2 & $373(350 \mathrm{i})$ & 4.09 .96 & - & - & 3 & - & $185 \mathrm{i}$ \\
\hline
\end{tabular}

${ }^{*}$ The genotype of this strain is $\mathrm{B}^{\mathrm{A}} \mathrm{B}^{\mathrm{A}}$

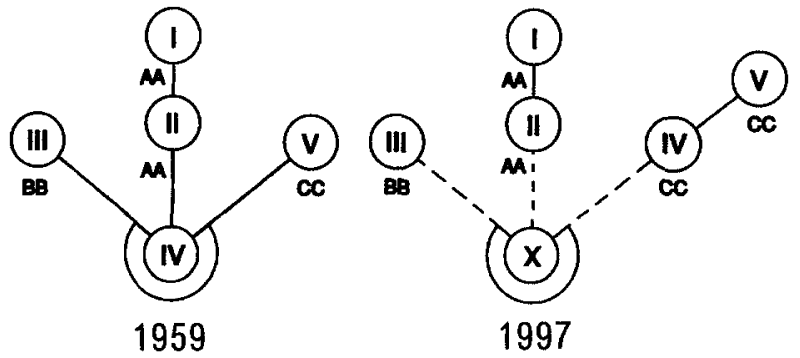

Fig. 4. Diagram of co-evolution of Oenothera genome and plastome from a common ancestor X, previous ("1959", after Stubbe 1959) and present ("1997") hypothesis origins of plastomes I, II, III and IV of subsection Oenothera. It is concluded that plastome IV must have diverged quite early from the other types and cannot be considered to be ancestral to them. However, the same sequence data can be interpreted in a different way leading to conflicting conclusions (Hornung et al. 1996). Therefore, additional non-repetitive parts of the cpDNA have to be considered for molecular analysis in order to support the classical genetic studies. To this end, earlier work by Wolfson et al. 1991 already provides some evidence for the relatedness of plastomes I and II and predicts a common progenitor for plastomes III and IV. But a more comprehensive 
W. Stubbe and E. Steiner: Genome-plastome incompatibility in Oenothera

Table 6. Progeny obtained from selfed Oenothera BB-IV plants

\begin{tabular}{|c|c|c|c|c|c|c|c|c|}
\hline Strain & $\begin{array}{l}\text { Culture } \\
\text { number } \\
\text { of parent }\end{array}$ & $\begin{array}{l}\text { Date of } \\
\text { selfing }\end{array}$ & $\begin{array}{l}\text { Seeds } \\
\text { sown }\end{array}$ & $\begin{array}{l}\text { Viable } \\
\text { BB-IV }\end{array}$ & $\begin{array}{l}\text { Non } \\
\text { viable }\end{array}$ & $\begin{array}{l}\text { Seeds not } \\
\text { germinated } \\
\text { with embro }\end{array}$ & $\begin{array}{l}\text { Empty } \\
\text { seeds }\end{array}$ & $\begin{array}{l}\text { Culture } \\
\text { number } \\
\text { (grown) }\end{array}$ \\
\hline \multirow[t]{2}{*}{ Avalon } & $96-460$ & 28.07. & 25 & - & - & - & 25 & $97-54 \mathrm{a}$ \\
\hline & $96-460$ & 4.09 & 30 & 16 & - & - & 14 & $97-54 b$ \\
\hline \multirow{2}{*}{ Bay Minette A } & $96-328-2$ & 28.07 & 30 & 24 & - & 4 & 2 & $97-53 \mathrm{a}$ \\
\hline & $96-328-2$ & 23.08 & 30 & 14 & - & 4 & 12 & $97-53 b$ \\
\hline \multirow[t]{5}{*}{ Bellamy } & $92-139-1$ & 1.07. & 30 & 3 & 7 & - & 20 & $95-40$ \\
\hline & $92-139-2$ & 21.07. & 30 & 2 & - & - & 28 & $94-630$ \\
\hline & $93-337-4$ & 6.07 & 80 & 25 & 12 & - & 43 & $94-905,95-41$ \\
\hline & $93-337-4$ & 1.08 & 30 & 4 & 11 & - & 15 & $95-42$ \\
\hline & $93-340-2$ & 1.08 & 60 & 27 & 7 & - & 26 & $95-36$ \\
\hline \multirow[t]{3}{*}{ Bigbee } & $91-300$ & 19.07 & 62 & - & - & - & 62 & $94-633 a$ \\
\hline & $91-300$ & 3.10 & 65 & - & - & - & 65 & $94-633 c$ \\
\hline & 94-909 & 27.09 & 40 & - & - & - & 40 & $95-48$ \\
\hline \multirow[t]{2}{*}{ Bolinger } & $90-70$ & 4.08. & 95 & - & - & - & 95 & $91-306$ \\
\hline & $96-357 \mathrm{~b}$ & 25.07 & 30 & - & - & - & 30 & $97-55$ \\
\hline Brewton & $92-150$ & 2.07 & 138 & - & - & - & 138 & $94-638$ \\
\hline \multirow[t]{3}{*}{ Cantonment } & $92-158$ & 2.10 & 96 & - & 4 & 2 & 90 & $94-640$ \\
\hline & $95-68$ & 18.07. & 30 & 23 & - & - & 7 & $96-338 a$ \\
\hline & $95-69$ & 20.07 & 30 & 30 & - & - & 0 & $96-368 c$ \\
\hline Castleberry B & $93-396$ & 1.08 & 27 & 9 & 6 & - & 12 & $94-922$ \\
\hline Chastang 2 & $96-375 b$ & 25.08 & 30 & 27 & - & - & 3 & $97-56$ \\
\hline Chastang $7^{*}$ & $92-171 b$ & 4.10. & 50 & - & - & - & 50 & $94-645$ \\
\hline \multirow[t]{2}{*}{ Flomaton } & $92-191$ a & 1.07. & 30 & 15 & 2 & - & 13 & $94-657$ \\
\hline & $94-935$ & 3.08 . & 33 & - & - & - & 33 & $96-388 \mathrm{a}$ \\
\hline \multirow[t]{2}{*}{ Frankville } & $92-209 b$ & 2.07 & 38 & 17 & - & - & 21 & $93-435$ \\
\hline & $94-939$ & 10.08 & 80 & 2 & 9 & - & 69 & $95-193$ \\
\hline Seabury Creek 1 & $94-951-3$ & 2.07 & 40 & - & - & - & 40 & $96-408 \mathrm{a}$ \\
\hline \multirow[t]{2}{*}{ Seabury Creek 2} & $93-469-1$ & 1.08 & 60 & 24 & 7 & 29 & 0 & $96-414$ \\
\hline & 94-958 & 5.09 & 60 & 2 & 13 & 1 & 44 & $95-115$ \\
\hline \multirow[t]{4}{*}{ Sims Chapel } & $92-270$ & 20.08 & 113 & - & - & - & 113 & $93-475$ \\
\hline & $92-272$ & 20.08 & 67 & 51 & - & - & 16 & $93-478$ \\
\hline & $93-478$ & 17.09 & 60 & 13 & 6 & - & 41 & $95-126$ \\
\hline & $95-126$ & 22.08 & 30 & 1 & 1 & - & 28 & $96-429 a$ \\
\hline Stockton 1 & $92-277$ & 1.07 & 80 & 1 & - & - & 79 & $93-485$ \\
\hline \multirow[t]{3}{*}{ Stockton 2} & $91-435$ & 19.07. & 50 & 3 & 1 & 2 & 44 & $92-285 b$ \\
\hline & $92-285$ b-1 & 15.07 & 40 & 9 & - & - & 31 & $93-490$ \\
\hline & $92-285 b-2$ & 15.07 & 30 & - & 1 & - & 29 & $94-703$ \\
\hline \multirow[t]{4}{*}{ Stockton derived } & $91-360-1$ & 22.08 & 34 & 26 & - & - & 12 & $93-440$ \\
\hline & $92-213-2$ & 18.08 & 40 & 32 & 1 & - & 7 & $93-444$ \\
\hline & $92-213-3$ & 18.08 & 55 & 37 & 1 & - & 17 & $94-675$ \\
\hline & $94-677$ & 5.09 & 60 & 38 & 3 & - & 19 & $95-102$ \\
\hline \multirow[t]{5}{*}{ Tuscaloosa } & $91-442$ & 18.08 & 40 & 27 & 2 & - & 11 & $92-290$ \\
\hline & $92-287$ & 19.08 & 35 & 17 & 1 & - & 17 & $94-706$ \\
\hline & $92-290-1$ & 19.08 & 72 & 11 & 3 & 2 & 56 & $94-708$ \\
\hline & $92-290-2$ & 19.08 & 60 & 24 & 1 & - & 35 & $94-709$ \\
\hline & 94-709 & 28.07 & 40 & 39 & - & - & 1 & $96-444 \mathrm{~b}$ \\
\hline \multirow[t]{2}{*}{ York } & $92-297$ & 18.08 & 60 & 15 & 1 & - & 44 & $93-501$ \\
\hline & $93-501$ & 6.07 & 140 & 76 & 2 & - & 62 & $94-978,96-445 b$ \\
\hline
\end{tabular}

* The genotype of this strain in $\mathrm{B}^{\mathrm{A}} \mathrm{B}^{\mathrm{A}}$. 
comparative analysis regarding all five plastomes and several different sets of repetitive as well as nonrepetitive DNA sequences is needed to further clarify the evolutionary history within the subsection Oenothera.

Financial support for this work was provided in part by a grant from the Deutsche Forschungsgemeinschaft. We thank Mrs. G. Linne von Berg and Mrs. E. Schumacher for excellent technical assistance and Dr. S. Miséra for his help on preparing the manuscript.

\section{References}

Chiu W.-L., Sears B. B. (1993) Plastome-genome interactions affect plastid transmission in Oenothera. Genetics 133: 989-997.

Cleland R. E. (1972) Oenothera: Cytogenetics and evolution. Academic Press, London New York.

Dietrich W., Wagner W., Raven P. H. (1997) Systematics of Oenothera section Oenothera subsection Oenothera (Onagraceae). Syst. Bot. Monogr. 50: 1-234.

Göpel G. (1967) Untersuchungen über die plastomabhängige Pollensterilität bei Oenothera. Inaugural-Dissertation Universität Köln.

Göpel G. (1970) Plastomabhängige Pollensterilität bei Oenothera. Theor. Appl. Genet. 40: 111-116.

Göpel G. (1976) Stoffwechseländerungen in plastomabhängig inaktiviertem Pollen von Oenothera. Z. Pflanzenphysiol. 78: 411-415.

Harte C. (1994) Oenothera: Contributions of a plant to biology. Springer, Berlin Heidelberg New York.

Hornung S., Fulgosi H., Dörfel P., Herrmann R. G. (1996) Sequence variation in the putative replication origins of the five genetically distinct basic Euoenothera plastid chromosomes (plastomes). Molec. Gen. Genet. 251: 609_ 612.

Kutzelnigg H. (1968) Versuche zur Auslösung von Plastommutationen bei Oenothera. Inaugural-Dissertation, Universität Düsseldorf.

Medgyesy P., Fejes E., Maliga P. (1985) Interspecific chloroplast recombination in a Nicotiana somatic hybrid. Proc. Natl. Acad. Sci. USA 82: 6960-6964.

Raven P. H., Dietrich W., Stubbe W (1979) An outline of the sytematics of Oenothera subsect. Euoenothera (Onagraceae). Syst. Bot. 4: 242-252.

Renner O. (1916) Die tauben Samen der Oenothera. Ber. Deutsch. Bot. Ges. 34: 858-869.

Renner O. (1919) Oenothera Lamarckiana und ihre Bedeutung für die Mutationstheorie und für die Bastardforschung. Sitzungsber. Ges. Morphol. Physiol. München 31: 1-6.

Renner O. (1942) Über das Crossing-over bei Oenothera. Flora 136: 117-214.

Schötz F. (1954) Über Plastidenkonkurrenz bei Oenothera. Planta 43: 182-240.
Schötz F. (1958) Beobachtungen zur Plastidenkonkurrenz bei Oenothera und Beiträge zum Problem der Plastidenvererbung. Planta 51: 173-185.

Schötz F. (1974) Untersuchungen über die Plastidenkonkurrenz bei Oenothera. IV. Der Einfluß des Genoms auf die Durchsetzungsfähigkeit der Plastiden. Biol. Zentralbl. 93: 41-64.

Schötz F. (1975) Untersuchungen über die Plastidenkonkurrenz bei Oenothera. V. Die Stabilität der Konkurrenzfähigkeit bei Verwendung verschiedenartiger mutierter Testplastiden. Biol. Zentralbl. 94: 17-26.

Schumacher E., Steiner E. (1993) Cytological analysis of complex-heterozygotes in populations of Oenothera grandiflora (Onagraceae) in Alabama. Plant Syst. Evol. 184: 77-87.

Schumacher E., Steiner E., Stubbe W. (1992) The complexheterozygotes of Oenothera grandiflora L'Her. Bot. Acta 105: 375-381.

Sears B., Stoike L. L., Chiu W.-L. (1996) Proliferation of direct repeats near the Oenothera chloroplast DNA origin of Replication. Molec. Biol. Evol. 13: 850-863.

Steiner E. (1956) New aspects of the balanced lethal mechanism in Oenothera. Genetics 41: 486-500.

Steiner E. (1957) Further evidence of an incompatibility allele system in the complex-heterozygotes of Oenothera. Amer. J. Bot. 44: 582-585.

Steiner E., Stubbe W. (1984) A contribution to the population biology of Oenothera grandiflora L'Her. Amer. J. Bot. 71: 1293-1301.

Steiner E., Stubbe W. (1986) Oenothera grandifiora revisited: A new view of its population structure. Bull. Torrey Bot. Club. 113: 406-412.

Stubbe W. (1953) Genetische und cytologische Untersuchungen an verschiedenen Sippen von Oenother suaveolens. Z. Indukt. Abstammungs-Vererbungsl. 85: 180209.

Stubbe W. (1955) Erbliche Chlorophylldefekte bei Oenothera. Photogr. Wiss. 4: 3-8.

Stubbe W. (1958) Dreifarbenpanaschierung bei Oenothera. II. Wechselwirkung zwischen Geweben mit zwei erblich verschiedenen Plastidensorten. Z. Vererbungsl. 89: 189203.

Stubbe W. (1959) Genetische Analyse des Zusammenwirkens von Genom und Plastom bei Oenothera. Z. Vererbungsl. 90: 288-298.

Stubbe W. (1960) Untersuchungen zur genetischen Analyse des Plastoms von Oenothera. Z. Bot. 48: 191-218.

Stubbe W. (1963) Extrem disharmonische Genom-PlastomKombinationen und väterliche Plastidenvererbung bei Oenothera. Z. Vererbungsl. 94: 392-411.

Stubbe W. (1964) The role of the plastome in evolution of the genus Oenothera. Genetica 35: 28-35.

Stubbe W. (1970) Das Falcifolia-Syndrom der Oenotheren. 1. Mitteilung. Molec. Gen. Genet. 106: 213-227.

Stubbe W. (1980) Über die Bedingungen der Komplexheterozygotie und die beiden Wege der Evolution komplexheterozygotischer Arten bei Oenothera. Ber. Deutsch. Bot. Ges. 93: 441-447. 
Stubbe W. (1989a) The falcifolia syndrom of Oenothera. III. The general pattern of its non-Mendelian inheritance. Molec. Gen. Genet. 218: 499-510.

Stubbe W. (1989b) The falcifolia syndrom of Oenothera. IV. Loss of falcifolia-determining factors. Molec. Gen. Genet. 218: 511-515.

Stubbe W. (1989c) Oenothera - An ideal system for studying the interactions of genome and plastome. Pl. Molec. Biol. Reporter 7: 245-257.

Stubbe W., Raven P. H. (1979a) A genetic contribution to the taxonomy of Oenothera sect. Oenothera (including subsection Euoenothera, Emersonia, Raimannia and Munzia). Plant Syst. Evol. 133: 39-59.

Stubbe W., Raven P. H. (1979b) Genetic self-incompatibility in Oenothera subsect. Euoenothera. Science 204: 327.

Stubbe W., Pietsch B., Kowallik K. V. (1978) Cytologische Untersuchungen über väterliche Plastidenvererbung und plastomabhängige Degeneration der Samenanlagen bei einem Oenothera-Bastard. Biol. Zentralbl. 97: 39-52.

Wasmund O. (1984) Genetische und zytologische Untersuchungen an verschiedenen Sippen von Oenothera nutans Atkinson. Inaugural-Dissertation, Universität Düsseldorf.

Wasmund O., Stubbe W. (1986) Cytogenetic investigations on Oenothera wolfi (Onagraceae). Plant Syst. Evol. 154: 79-88.

Wolfson R., Higgins K. G., Sears B. B. (1991) Evidence for replication slippage in the evolution of Oenothera chloroplast DNA. Molec. Biol. Evol. 8: 709-720.

Addresses of the authors: Prof. Dr. Wilfried Stubbe, Botanical Institute and Botanical Garden, Heinrich-HeineUniversity Düsseldorf, Universitätsstraße 1, D-40225 Düsseldorf, Germany. Prof. Dr. Erich Steiner, Department of Biology and Matthaei Botanical Gardens, University of Michigan, Ann Arbor, Michigan, 48109 USA. 